\title{
Transcriptional Regulation of Thrombospondins and Its Functional Validation through CRISPR/Cas9 Mediated Gene Editing in Corpus Luteum of Water Buffalo (Bubalus Bubalis)
}

\author{
Avishek Paula Jaya Bharatia Meeti Punetha ${ }^{a} \quad$ Sai Kumar ${ }^{a} \quad$ Vidyalakshmi G M ${ }^{a}$ \\ Vikrant S Chouhan ${ }^{a} \quad$ Arvind Sonwane $^{b} \quad$ Sadhan Bag $^{a}$ Sanjeev Kumar Bhure \\ Vijai Prakash Maurya ${ }^{\mathrm{a}} \quad$ Gyanendra Singh $^{\mathrm{a}} \quad$ Kristin M Whitworth ${ }^{\mathrm{d}}$ Mihir Sarkar $^{\mathrm{a}}$ \\ aIndian Veterinary Research Institute, Physiology \& Climatology Division, Bareilly, India, 'ndian \\ Veterinary Research Institute, Division of Animal Genetics, Bareilly, India, Indian Veterinary Research \\ Institute, Division of Biochemistry, Bareilly, India, dUniversity of Missouri-Columbia, Division of Animal \\ Science, Columbia, MO, USA
}

\section{Key Words}

Buffalo $•$ Corpus luteum $・$ TSP $•$ CRISPR/Cas9 $•$ Luteolysis

\begin{abstract}
Background/Aims: Thrombospondins (TSPs) are large multi-modular proteins, identified as natural angiogenesis inhibitors that exert their activity by binding to CD36 and CD47 receptors. The anti-angiogenic effect of TSPs in luteal regression of water buffalo has not been addressed. The present study characterized the expression pattern and localization of TSPs and their receptors in ovarian corpus luteum during different stages of development in buffalo. This study also elucidated the effect of exogenous Thrombospondin1 (TSP1) or the knocking out of the endogenous protein on luteal cell viability and function. Further, the in vitro transcriptional interaction of TSP1 with hormones, LH, PGF2 $\alpha$ and angiogenic growth factors, VEGF and FGF2 were also evaluated. Methods: First, the CLs were classified into four groups based on macroscopic observation and progesterone concentration. mRNA expression of examined factors was measured by qPCR, localization by immunoblotting and immunohistochemistry. TSP1 was knocked out (KO) in cultured luteal cells isolated from late luteal stage CLs (day 1116) by CRISPR/Cas9 mediated gene editing technology in order to functionally validate the TSP1 gene. Isolated cells from late stage CLs were also stimulated with different doses of TSP1, $\mathrm{LH}, \mathrm{PGF} 2 \alpha$, VEGF and FGF2 for various time intervals to determine transcriptional regulation of thrombospondins. Results: mRNA expression of TSPs and their receptors were found to
\end{abstract}


be significantly higher in late and regressed stage of $C L$ as compared to other groups which was consistent with the findings of immunoblotting and immunolocalization experiments. It was observed that TSP1 induced apoptosis, down regulated angiogenic growth factors, VEGF and FGF2 and attenuated progesterone production in cultured luteal cells. However, knocking out of endogenous TSP1 with CRISPR/Cas9 system improved the viability of luteal cells, progesterone synthesis and upregulated the expression of VEGF and FGF2 in the KO luteal cells. PGF2 $\alpha$ induced the upregulation of TSPs and Caspase 3 transcripts, whereas treatment with LH and angiogenic growth factors (VEGF and FGF2) down regulated the TSP system in luteal cells. Conclusion: Collectively, these data provide evidence that thrombospondins along with their receptors are expressed at varying levels in different stages of $C L$ progression with maximum expression during the late and regressing stages. These results are consistent with the hypothesis that thrombospondins stimulated by PGF2 $\alpha$ plays an essential modulatory role in bringing about structural and functional luteolysis in buffalo.

\section{Introduction}

Physiological angiogenesis in the ovary is a tightly controlled process which provides a unique opportunity to study angiogenic processes, as it is one of the few tissues in the female adult that undergoes repetitive blood vessel formation, maturation, and regression [1]. The corpus luteum (CL) is one such tissue in the ovary that exhibit regular periods of growth (angiogenesis), steroidogenic function and luteolysis (CL regression). Prolonged anestrous and inadequate progesterone production has been associated with inadequate angiogenesis in the CL resulting into poor embryo development and increased pregnancy failure in the buffalo cow [2-3].

The stringency in the process of ovarian angiogenesis is modulated by various pro and anti-angiogenic factors. Several pro-angiogenic factors are well-known; however, those that seem to be the most important in ovarian angiogenesis are FGF2, VEGF and ANG II [4-6]. On the contrary, a number of naturally occurring inhibitors of angiogenesis have been identified in mammalian tissues which have been considered to maintain quiescence of the normal vasculature. The thrombospondin family consisting of TSP1 and TSP2, are large, secreted, multimodular glycoproteins that play complex roles in mediating cellular processes. TSPs function in cell-cell and cell-matrix interactions as potent inhibitors of angiogenesis [7]. The cellular effects of the TSPs are mediated through interaction with cell-surface receptors CD36 and Integrin Associated Protein (IAP, also known as CD47) [8]. In the cow ovary, TSP and CD36 protein were co-localized in the granulosa cells of small and medium antral follicles $(0.5-1 \mathrm{~cm})$, with reduced expression of TSP mRNA and protein in larger follicles [9]. The same pattern of expression has also been found in primate ovary [7].

It is reasonable to assume that there may exist cross-talk between pro-and anti-angiogenic factors regulating the complex angiogenic process in ovary. Recently, several studies have focused on the different actions of $\mathrm{PGF}_{2} \alpha$ on steroidogenesis, immune function and vasoactive factors between the early CL ( $\mathrm{PGF}_{2} \alpha$ resistant) and mid CL ( $\mathrm{PGF}_{2} \alpha$ responsive) in domestic animals [10]. Our lab previously reported that LH plays an important role in stimulating luteal angiogenesis in buffalo CL [11]. In addition, a role for TSP1 in inhibition of VEGF levels has been demonstrated in TSP1 knockout mice, which exhibit follicular hypervascularization and reduced litter size. The loss of the inhibitory effect of TSP1 in TSP1-null mice results in increased levels of follicular VEGF [9]. TSP1 also combines with pro-angiogenic FGF2, consequently lowering its bioavailability and activity [12]. The pro-apoptotic properties of TSP1, coupled with its ability to inhibit FGF2 expression and activity, may prove to be critical for luteal regression [13]. A characterization of the interaction between TSP1, VEGF \& FGF2 has not yet been documented in the buffalo ovary. We hypothesize that the TSP family could be involved in the luteolytic mechanism in buffalo. 


\section{$\begin{array}{ll}\text { Cellular Physiology } & \text { Cell Physiol Biochem 2019;52:532-552 } \\ \text { DOl: 10.33594/000000038 } & \text { 2019 The Author(s). Published by }\end{array}$ \begin{tabular}{lll} 
and Biochemistry & $\begin{array}{l}\text { DOl: 10.33594/000000038 } \\
\text { Published online: } 22 \text { March } 2019\end{array}$ & $\begin{array}{l}\text { O } 2019 \text { The Author(s). Published by } \\
\text { Cell Physiol Biochem Press GmbH\&Co. KG }\end{array}$ \\
\cline { 2 - 3 }
\end{tabular}

The field of biology is presently experiencing a transformative phase with the advancement of refined genome engineering technology in animal and plants using RNAprogrammable CRISPR/Cas9. This gene editing system is paving the way for understanding how these genes function and possibly harnessing them to improve health in both humans and other animals. Therefore, the present study was designed to investigate the expression and localization of TSPs and their receptors in ovarian corpus luteum during different stages of development in buffalo. The objective of this study it to determine the effects of exogenous administration of TSP1 as well as CRISPR/Cas9 mediated knocking out of the endogenous protein TSP1 on luteal cell viability and function. Subsequently, we further aim to study the transcriptional interaction of TSP1 with LH, PGF2 $\alpha$, VEGF and FGF2 in in vitro luteal cell culture system.

\section{Materials and Methods}

Collection of CL

Normal reproductive tracts from buffalo cows were collected from a local slaughter house within 30 mins post slaughter and were transported in ice cold conditions to the laboratory. The stage of the estrous cycle was defined by macroscopic observation of the ovaries (color, consistency, CL stage, number, and size of follicles) and the uterus (color, consistency, and mucus) as described previously [14]. Forty (40) ovaries, with CL, were distributed to following stages $(n=10$; in each stage): early luteal stage (days 1-4), mid luteal stage (days 5-10), late luteal stage (days 11-16), and regressed CL (days $>17$ ) of estrous cycle for RNA extraction, immunoblotting, and immunohistochemistry studies. Luteal tissues were snap frozen in liquid nitrogen and stored at $-80^{\circ} \mathrm{C}$ until RNA and protein isolation [15].

\section{Primers}

The primers for TSP1, TSP2, CD36, CD47 and Caspase 3 were designed using the DNAStar, Gene tool and Oligo Analyzer software. Previously published primers were used for FGF2, VEGF, RPS15A and GAPDH $[4-5,14]$. Details of the primers used are presented in Table 1.

\section{qPCR analysis}

Total RNA was isolated from different stages of CL by QIAzol reagent (QIAGEN) according to manufacturer's instructions. The RNA samples were treated with RNase free DNase and subsequently DNase was inactivated by heating at $56^{\circ} \mathrm{C}$ for $10 \mathrm{~min}$ and immediately chilled at $4^{\circ} \mathrm{C}$. The quality of RNA was checked by A260/A280 ratio using a Nanodrop spectrophotometer. Distinct 28S and 18S RNA bands

Table 1. Target gene, primer sequences and amplicon length used in the qPCR and knockout study

\begin{tabular}{|c|c|c|c|}
\hline Gene & Sequences of nucleotide $\left(5^{\prime}-3^{\prime}\right)$ & Amplicon length & EMBL accession no.or \\
\hline TSP1 & $\begin{array}{c}\text { Forward: TGCCCCAACCTTCCCAACTCG } \\
\text { Reverse: ACAGCGGTCTCCCACGTCATCTCT }\end{array}$ & 171 & XM_006073071.1 \\
\hline TSP2 & $\begin{array}{l}\text { Forward: CGAGAGGAGCCGGATGTATGTGTGG } \\
\text { Reverse: TCAGGTGCAGCGTCTCCGTGTTCT }\end{array}$ & 185 & XM_006061369.1 \\
\hline CD36 & $\begin{array}{l}\text { Forward: AATTGGGTTAAAACAGGCACAGAT } \\
\text { Reverse: TGGGTTACATTTTCCTTGGCTAGA }\end{array}$ & 158 & KC507892.1 \\
\hline CD47 & $\begin{array}{l}\text { Forward: GCAGAGAAGGGGAAACCATCA } \\
\text { Reverse: GGCTTTCTCCTTCGTATAATTGG }\end{array}$ & 170 & NM_174708.2 \\
\hline VEGF & $\begin{array}{l}\text { Forward: CCATGAACTTTCTGCTCTCTTGG } \\
\text { Reverse: TCCATGAACTTCACCACTTCG }\end{array}$ & 133 & NM-174216.1 \\
\hline FGF2 & $\begin{array}{l}\text { Forward: AAACCGTTACCTTGCTATG } \\
\text { Reverse: TGCCCAGTTCGTTTCAGT }\end{array}$ & 159 & NM_174056. 3 \\
\hline Caspase 3 & $\begin{array}{l}\text { Forward: CAGGGTGCCCAGGACTTTAG } \\
\text { Reverse: AGAAAGCTCACGGGAACCAG }\end{array}$ & 165 & NM_001077840. 1 \\
\hline RPS15A & $\begin{array}{l}\text { Forward: AGGGCTGGGAAAATTGTTGTGAA } \\
\text { Reverse: TGAGGGGATGGGAGCAGGTTAT }\end{array}$ & 104 & [5] \\
\hline GAPDH & $\begin{array}{l}\text { Forward: GCGATACTCACTCTTCTACTTTCGA } \\
\text { Reverse: TCGTACCAGGAAATGAGCTTGAC }\end{array}$ & 82 & U85042.1 \\
\hline $\begin{array}{l}\text { TSP1 } \\
\text { SgRNA }\end{array}$ & $\begin{array}{l}\text { Forward: TAATACGACTCACTATAGATCCTCGATGCGGA } \\
\text { Reverse:TTCTAGCTCTAAAACGCTTTCCGCATCGAGGAT }\end{array}$ & - & \\
\hline
\end{tabular}




\section{Cellular Physiology Cell Physiol Biochem 2019;52:532-552

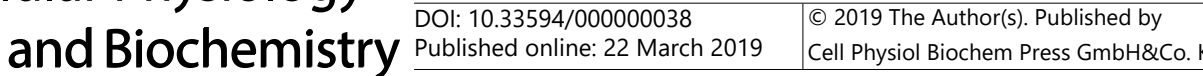 \\ Paul et al.: Thrombospondins and Corpus Luteum Function}

indicated extracted total RNA was intact after RNA gel electrophoresis. One (1) microgram of total RNA from different samples was reverse transcribed into cDNA using RevertAid First cDNA synthesis kit (ThermoFisher Scientific) according to manufacturer's instruction using oligo dT primers at $42^{\circ} \mathrm{C}$ for 60 min. Quantitative real-time PCR was performed using Ssofast Eva Green®qPCR kit, Biorad, USA. A general qPCR protocol was followed with initial denaturation at $95^{\circ} \mathrm{C}$ for 30 s followed by 40 cycles of denaturation at $95^{\circ} \mathrm{C}$ for $5 \mathrm{~s}$, annealing and extension at $60^{\circ} \mathrm{C}$ for $10 \mathrm{~s}$. Cycle threshold (cT) values and amplification plot for all determined factors were acquired using the "Eva green (with dissociation curve)" method of the real-time machine (Biorad CFX manager Real-Time qPCR $^{\mathrm{TM}}$ software). Real time PCR efficiencies were determined by amplification of a standardized dilution series, and slopes were obtained. A negative control containing all components except template was included for each sample to rule out the formation of primer dimer and non-specific amplification.

\section{Antibodies and Growth factor}

Immunoblotting and immunohistochemistry were performed using goat polyclonal GAPDH (sc-48166; Santa Cruz Biotechnology, Inc., Dallas, TX), mouse monoclonal TSP1 (sc-393504; Santa Cruz Biotechnology, Inc., Dallas, TX), goat polyclonal TSP2 (sc-12313; Santa Cruz Biotechnology, Inc., Dallas, TX), goat polyclonal CD36 (sc-5522; Santa Cruz Biotechnology, Inc., Dallas, TX), mouse anti-goat IgG-HRP (sc-2354; Santa Cruz Biotechnology, Inc., Dallas, TX), goat anti-mouse IgG-HRP (sc-2005; Santa Cruz Biotechnology, Inc., Dallas, TX) bovine anti-goat IgG-CFL-647 (sc-362284, Lot\#B0312) and goat anti-mouse IgG-CFL-647 (sc362257; Santa Cruz Biotechnology, Inc.). Recombinant Human Thrombospondin1 (Catalog no. 3074-TH, R\&D Systems), LH (bovine LH; AFP 117438-NHPP-NIDDK), Prostaglandin F2 alpha (Catalog no. 194578; MP Biomedicals), Recombinant Human VEGF (Catalog no. 293-VE, R\&D Systems) and Recombinant bFGF-basic (bovine brain derived; Catalog no. 133-F13/CF, R\&D System) were procured for cell culture studies.

\section{Immunoblotting}

Total proteins from the 4 assigned CL stages were obtained by triturating of the stored tissues and resuspending in RIPA lysis (Ameresco) buffer and Halt protease inhibitor cocktail (Thermo Scientific). The suspensions were centrifuged at $12,000 \mathrm{~g}$ at $4^{\circ} \mathrm{C}$. The supernatants containing the total soluble protein were extracted and concentrations were estimated using Bradford protein assay. The protein samples were diluted in 2X Laemmli loading buffer and boiled for $5 \mathrm{~min}$. One hundred (100) $\mu \mathrm{g}$ of protein sample from each group of CL were subjected to $10 \%$ SDS polyacrylamide gel electrophoresis. For western blot analysis, the protein samples from the gel were electro transferred onto polyvinylidene difluoride membrane (PVDF) and blocked with $5 \%$ bovine serum albumin (BSA) before incubation with primary antibodies. The primary antibodies were against TSP1, TSP2 and CD36 which were used at a 1:500 dilution and polyclonal GAPDH antibody at a 1:400 dilution. After incubation for overnight at $4^{\circ} \mathrm{C}$, the membrane was washed with PBS-T (PBS $0.01 \%$ Tween 20). The respective secondary antibody conjugated with horseradish peroxidase was then added. After washing with PBS-T solution, the positive signals were detected by incubating the membrane in $0.06 \% 3$, 3'-diaminobenzidine tetrahydrochloride (Genei) in $1 \mathrm{X}$ PBS (pH 7.4) containing $0.06 \% \mathrm{H}_{2} \mathrm{O}_{2}$ for 10 to $15 \mathrm{~min}$. The distinct bands were visualized and recorded on a digital camera.

\section{Immunohistochemistry}

The freshly collected luteal tissues were fixed with $10 \%$ neutral buffer formalin. These fixed tissues were then dehydrated through a series of graded alcohols, embedded in paraffin and serial-sectioned (5 $\mu \mathrm{m}$ ). Sectioned samples were then mounted on 3-Aminopropyl triethoxysilane (Thermo Scientific) coated slides, and dried at $37^{\circ} \mathrm{C}$ overnight. Deparaffinization was performed in xylene followed by rehydration with a series of graded alcohols at room temperature. For epitope retrieval, the slides were treated in sodium citrate buffer (10 mM sodium citrate, $\mathrm{pH} 6.0,0.05 \%$ Tween- 20), rinsed, and blocked with 5\% BSA for $2 \mathrm{~h}$ at $37^{\circ} \mathrm{C}$. The morphology of the CL sections was first evaluated using hematoxylin and eosin staining, following a previously reported method [4]. Subsequently, sections were probed with TSP and its receptors antibodies, at 1:200 dilutions. Primary antibodies were detected by fluorescent conjugated bovine anti-goat and goat anti-mouse IgG-CFL-647 secondary antibodies. The slides were then rinsed and nuclei of the cells in the luteal sections were stained by adding $0.4 \mathrm{mg} / \mathrm{mL}$ of 4, 6-diamidino-2- phenylindole dihydrochloride (DAPI) in PBS. The control slides were processed under similar conditions except for the addition of isotype IgG and omission of the primary antibody. The stained fluorescent sections were mounted with antifade 


\section{Cellular Physiology Cell Physiol Biochem 2019;52:532-552 \\ \begin{tabular}{ll|l} 
and Biochemisty & $\begin{array}{l}\text { DOI: 10.33594/000000038 } \\
\text { Published online: 22 March } 2019\end{array}$ & $\begin{array}{l}\text { C } 2019 \text { The Author(s). Published by } \\
\text { Cell Physiol Biochem Press GmbH\&Co. KG }\end{array}$ \\
\hline
\end{tabular} \\ Paul et al.: Thrombospondins and Corpus Luteum Function}

mounting media (MP Biomedicals) and images were captured by using Axio Observer.Z1 (Carl Zeiss Micro Imaging $\mathrm{GmbH}$, Germany) microscope.

\section{Tissue collection and Luteal cell culture}

In order to study the effects of the TSP1, LH, PGF2 $\alpha$, VEGF and FGF2 on luteal function, a luteal cell culture model was established with cells isolated from fresh CLs. Ovaries were collected in $1 \mathrm{X}$ PBS at $37^{\circ} \mathrm{C}$ in a vacuum flask from a local abattoir. In all of the experiments, only late luteal stage (days 11-16) was used which were selected based on the established criteria applied previously in buffalo [6]. The luteal cell culture was developed using the protocol established in our laboratory [14]. In brief, cells (including luteal, endothelial, pericytes, and fibroblasts) were dispersed by incubating the luteal tissue in DMEM/ F12 medium (Hyclone, Thermo Scientific) containing collagenase, DNase I and BSA for 2 x45 mins in a shaker incubator at $37^{\circ} \mathrm{C}$. The dispersed cells, were then filtered through $70 \mu \mathrm{m}$ filter and after washing re-suspended in DMEM/F12 medium (HyClone; Thermo Scientific); containing 10\% fetal bovine serum (FBS) (Sigma-Aldrich) and Antibiotic-Antimycotic solution. The cell viability was determined by trypan blue exclusion dye. The cells were then plated out at $1.5 \times 10^{5}$ viable cells per well in a 24 -well plate with $1 \mathrm{ml}$ culture media in a humidified $\mathrm{CO}_{2}(5 \%)$ incubator at $37^{\circ} \mathrm{C}$. The cells were allowed to attach and grow $(75 \%-$ $80 \%$ confluent) for $48 \mathrm{~h}$. The media was then replaced with fresh media containing different concentrations of TSP1 (50, 100, and $500 \mathrm{ng} / \mathrm{ml})$, LH (5, 10 and $100 \mathrm{ng} / \mathrm{ml}$ media), PGF2 $\alpha$ analog $(0.1,1$ and $10 \mu \mathrm{g} / \mathrm{ml})$, $\operatorname{VEGF}(1,10$ and $100 \mathrm{ng} / \mathrm{ml})$ and FGF2 (1, 10 and $50 \mathrm{ng} / \mathrm{ml}$ media) individually and cultured for 24, 48 and $72 \mathrm{~h}$. Control cells were grown in media without hormone or growth factors. After the stipulated period of time, the media was assayed for $\mathrm{P}_{4}$ concentration and the cells were collected for mRNA isolation. Each treatment was tested in triplicate wells for each experiment.

\section{Production of Thrombospondin1 KO luteal cells}

Production of Thrombospondin1 knock out (TSP1 KO) luteal cells was accomplished by CRISPR/Cas 9 system mediated disruptions of the bubaline TSP1 genes. In this approach, components of CRISPR/Cas 9 system (Single guide RNA and Cas9) were delivered into the luteal cells via lipofection and the details of the methodology are mentioned below:

Preparation of Synthetic Single guide RNA (SgRNA). TSP1 gene specific guide RNA (20nt) was designed using available software. For SgRNA synthesis, the T7 promoter sequence was added to SgRNA template/ forward primer and the IVT template was then generated by PCR amplification using designed primers. Briefly, SgRNA DNA template was PCR amplified using the Phusion High-Fidelity PCR Master Mix in thermocycler followed by generation of SgRNA by in vitro transcription using the TranscriptAid Enzyme Mix (Invitrogen) and later the in vitro transcribed SgRNA was purified using the GeneJET ${ }^{\text {TM }}$ purification columns kit according to manufacturer's instruction (Invitrogen). Aliquots from an IVT reaction was separated on agarose gel to assess quality. Concentration of purified SgRNA was measured by Nanodrop spectrophotometry.

Transfection and Genomic Cleavage Detection. Ready to transfect wild-type Cas9 protein (GeneArt Platinum Cas9 Nuclease) for performing CRISPR/Cas9-mediated genome editing was procured from Invitrogen.

Cultured luteal cells of 30-70\% confluency were transfected with components of CRISPR/Cas9 and transfection reagent complex using Lipofectamine CRISPRMAX Transfection kit as per manufacturer's protocol (Invitrogen). Briefly, Cas9 nuclease/SgRNA/Cas9 Plus solution was prepared in one tube and the CRISPRMAX reagent was diluted in Opti-MEM medium in another tube and incubated for 5 minutes at room temperature. After that, solutions from both tubes were mixed properly and incubated for another 5-10 mins and then the mixture was added to the wells of culture plate containing the 30-70\% confluent luteal cells. Detection of TSP1 KO luteal cells was done by GeneArt Genomic Cleavage Detection Kit as per manufacturer's instruction (Invitrogen). The cleavage efficiency of the TSP1 knock out was measured by the following equation.

Cleavage efficiency $=$

[(sum of cleaved band intensities)/(sum of cleaved and parental band intensities )]× 100\% [16].

Following the above procedure, all the Thrombospondin1 (TSP1) KO luteal cells were cultured for 72 hrs in replicates of three for each treatment group. Cells were harvested to determine mRNA expression of genes. Media was stored at $-20^{\circ} \mathrm{C}$ until used in the $\mathrm{P} 4$ immunoassay. 


\section{Cellular Physiology Cell Physiol Biochem 2019;52:532-552 \\ \begin{tabular}{ll|l|l|l|l}
\hline DOl: 10.33594/000000038 & ( 2019 The Author(s). Published by \\
\hline
\end{tabular} \\ \begin{tabular}{l|l} 
Published online: 22 March 2019 & Cell Physiol Biochem Press GmbH\&Co. KG
\end{tabular} \\ Paul et al.: Thrombospondins and Corpus Luteum Function}

\section{Cell Viability Assay}

The primary culture luteal cells were seeded on 96 well plates and incubated at $37^{\circ} \mathrm{C}$ for 72 hours with media containing different concentrations $(50,100$, and $500 \mathrm{ng} / \mathrm{ml})$ of TSP1 $(50,100$, and $500 \mathrm{ng}$ / ml). TSP1 knocked out luteal cells were also cultured for 72 hour at $37^{\circ} \mathrm{C}$. After culture, $10 \mu \mathrm{lof} 5 \mathrm{mg} / \mathrm{ml}$ of 3-(4, 5-dimethylthiazole-2-yl)-2, 5-diphenyltertrazolium bromide (MTT; MP Biomedicals) was added to each well and cells were further cultured for 4 hours at $37^{\circ} \mathrm{C}$. Supernatant was then aspirated and $100 \mu \mathrm{l}$ of DMSO (MP Biomedicals) was added and absorbance at $450 \mathrm{~nm}$ was detected with a microplate reader (Biorad, Microplate reader).

\section{Apoptosis Assay}

The proportion of apoptotic cells was qualitatively measured by Annexin $\mathrm{V}$ apoptosis detection kit (BD bioscience). Both wild type and TSP1 knock out luteal cells were cultured at $37^{\circ} \mathrm{C}$ for 72 hours. Then, cells from both the groups were trypsinized using $0.05 \%$ Trypsin/EDTA solution and cells were harvested, treated with $5 \mu \mathrm{l}$ of both annexin V and PI according to manufacturer's instructions. The apoptotic signals were detected by Axio Observer.Z1 (Carl Zeiss Micro Imaging GmbH, Germany) microscope.

\section{Hormone Assay}

Concentrations of progesterone $\left(\mathrm{P}_{4}\right)$ in the spent media of luteal cell culture were estimated by $\mathrm{P}_{4}{ }^{125} \mathrm{I}$ RIA kit (IM1188) supplied by Immunotech, Czech Republic as per manufacturer's instructions. The intra and inter assay coefficients of variation were $7.4 \%$ and $8.7 \%$, respectively.

\section{Statistical Analyses}

All experimental data are shown as Mean \pm SEM. Efficiency-corrected relative quantification of mRNA was obtained by Pfaffl's method [17]. Statistical significance differences in mRNA expression of the examined factors across different stages of corpus luteum and the expression of protein was assessed by using the software SPSS.22 by one-way analysis of variance followed by Tukey's honestly significant difference (HSD) test. The $\mathrm{P}_{4}$ concentration and mRNA expression in cultured luteal cells were assessed using the software SPSS.22 by two-way analysis of variance followed by Tukey's HSD test as a multiple comparison test. Differences were considered significant at $p<0.05$.

\section{Results}

\section{Confirmation of primer specificity}

The mRNA expression was analyzed by conventional real time RT-PCR. For the exact length verification, the RT-qPCR products were separated on $2 \%$ agarose gel electrophoresis and visualized under UV light (Table 1).

\section{Expression analysis of TSP1, TSP2, CD36 and CD47 mRNA in the corpus luteum of water}

buffalo

The preovulatory follicle (PF) was used as calibrator for obtaining relative mRNA expression. Efficiencies of primers were determined by serial dilution of template cDNA sample and running in triplicate. The expression of RPS15A and GAPDH was examined in all the samples and geometric mean of $\mathrm{Ct}$ values of both the house keeping genes was used as $\mathrm{Ct}$ of reference gene. The relative change in the copy number of Thrombospondins and its receptor system during different stage of CL development in the buffalo is presented in Fig. 1. TSP1 transcripts were significantly upregulated during the late stages of CL progression as compared to other stages of CL and PF ( $p<0.05$; Fig. 1A). However, the relative fold change of TSP2 mRNA was significantly upregulated during both late and regressed stage CL as compared to other stages ( $p<0.05$; Fig. 1B). The mRNA expression of CD36 receptor was nonsignificant in the early stages and PF, however, the messages of CD36 showed significant and continuous upregulation to a maximum level in the corpora lutea during regression stage $(p<0.05$; Fig. 1C). In contrast, CD47 receptor showed significantly higher upregulation only in regressed stage of CL when compared to other stages and as well as PF (Fig. 1D). Taken 


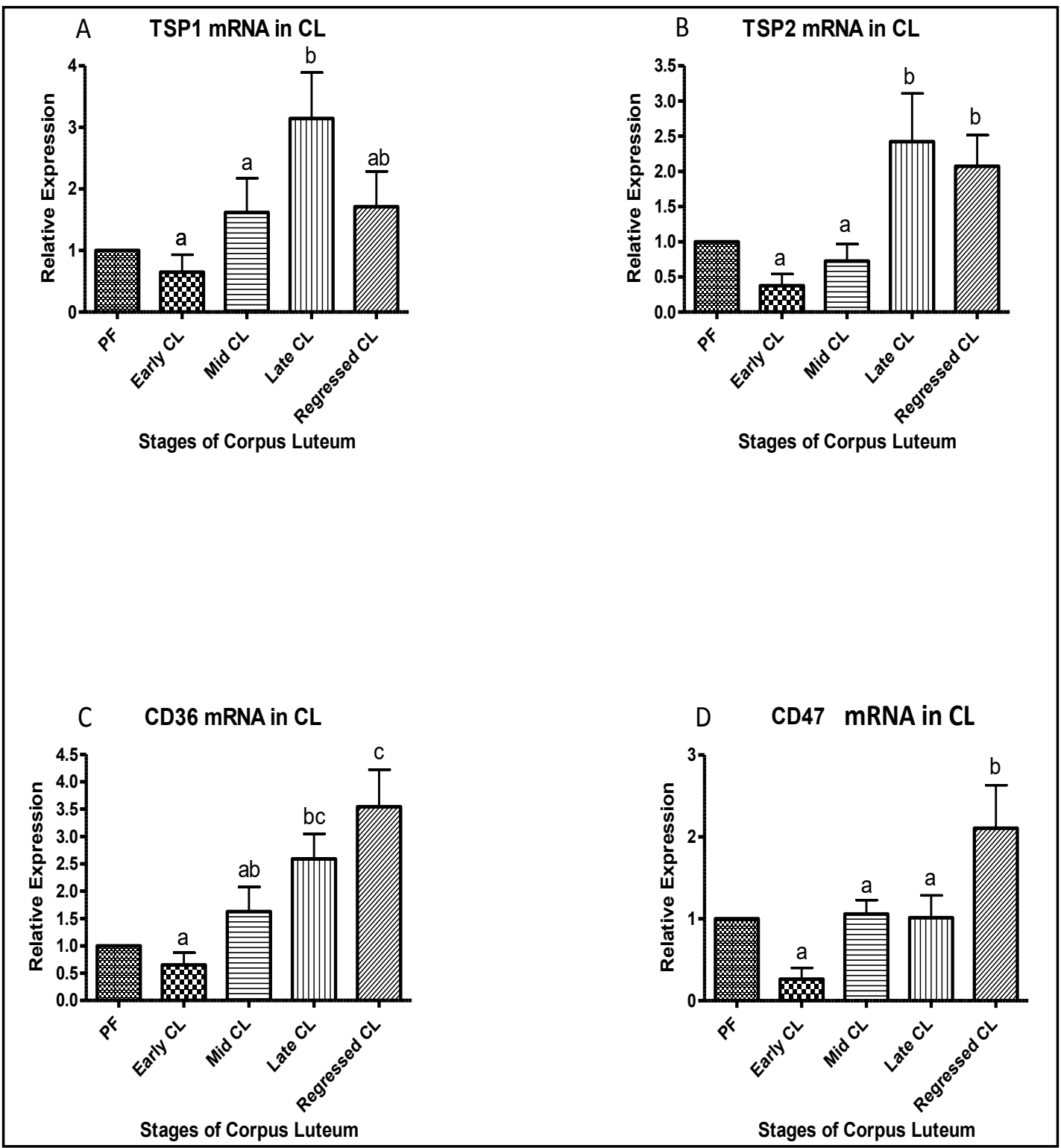

Fig. 1. Transcriptional profile of (A) TSP1, (B) TSP2, (C) CD36 and (D) CD47 at different stages of CL development in the riverine buffalo ( $\mathrm{n}=10$ /group). (early $\mathrm{CL}$, days $1-4$, mid CL, days 5-10, late CL, days 11-16, and regressed CL, days $>17$ of estrous cycle). The PF served as calibrator group to calculate the fold change. RPS15A and GAPDH were used as reference gene to calculate $\Delta \mathrm{Ct}$ (delta $\mathrm{Ct}$ ). Results are presented as Mean \pm SEM. Different superscripts denote statistically significant $(\mathrm{p}<0.05)$. Abbreviations: CL, Corpus Luteum; mRNA, Messenger RNA; TSP, Thrombospondin; CD, Cluster of differentiation; PF, Preovulatory follicle.

together, the real-time PCR data indicated that late stage CL showed significantly increased expression of TSPs and CD36.

\section{Immunoblotting Analysis}

Western blot showed that both TSP1 \& TSP2 as well as their receptor CD36 are present in the CL of the buffalo (Fig. 2A). Semi-quantitative analyses of the blots using band densitometry revealed that the TSP1 protein expression was higher at late stage CL than the other stages $(p<0.05$; Fig. $2 \mathrm{~B})$. However, TSP2 proteins showed a significant upregulation trend in late and regressed stages of CL as compared to other stages $(p<0.05$; Fig. $2 \mathrm{C})$. The 


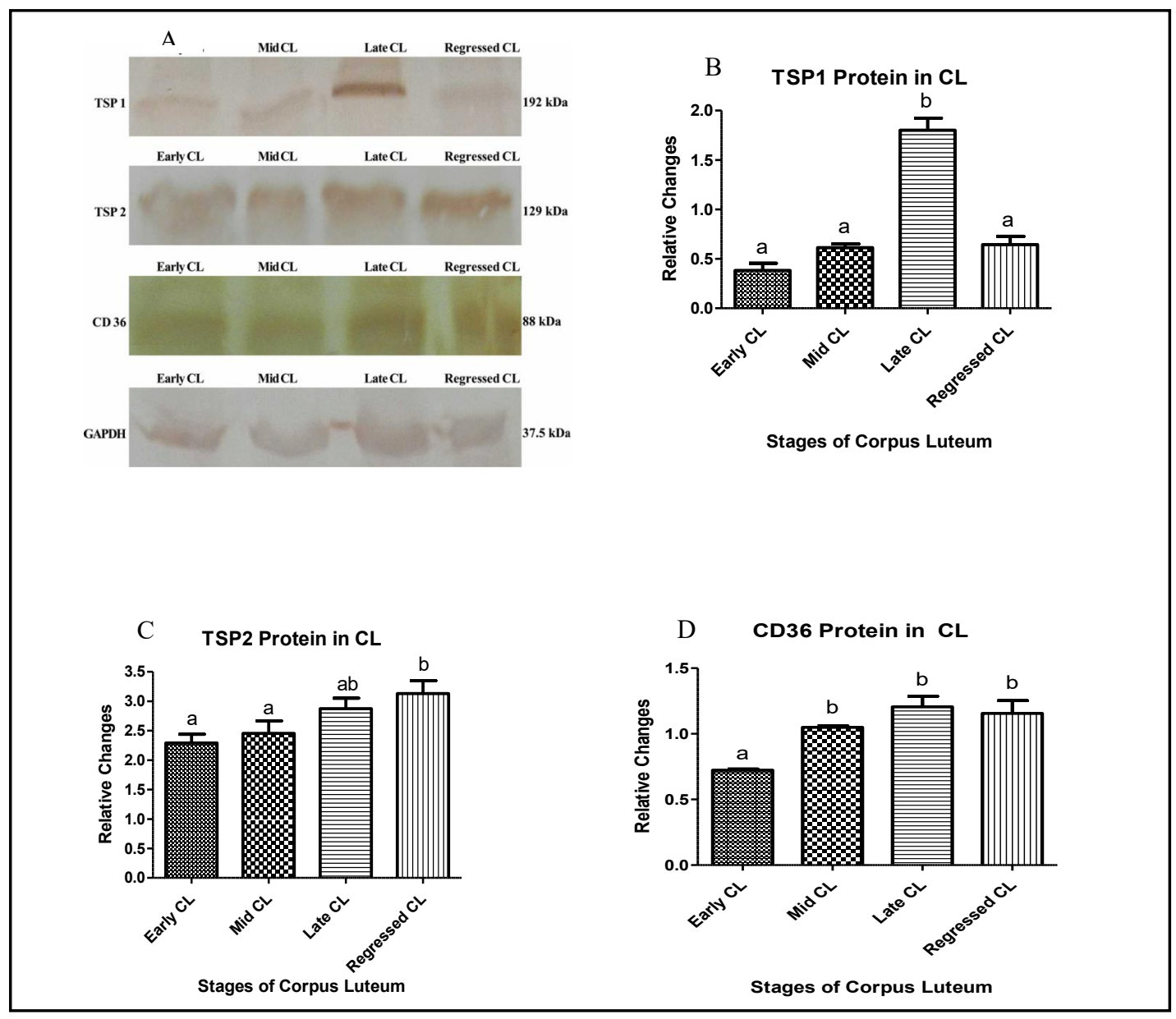

Fig. 2. Demonstration of (A) representative blots of TSP1, TSP2, CD36 and GAPDH by immunoblotting at different stages of CL development in the riverine buffalo. The relative molecular weight of each protein is shown along the right side of each blot. The luteal proteins were loaded @ $100 \mathrm{mg} /$ well and resolved in 10\% SDS-PAGE followed by electrotransfer to a PVDF membrane. Protein specific antibodies were used @ 1:500 while secondary antibody @1:2000 dilutions. GAPDH was used as reference protein. Relative expression of TSP and its receptors was analysed by densitometry using image J software $(n=6 /$ group). One-way ANOVA to determine if treatment groups were significantly different. Tukey HSD test was done to find the pair-wise mean differences. Each bar represents Mean \pm SEM. Different superscripts denote statistical significance $(p<0.05)$. Abbreviations: CL, Corpus Luteum; TSP, Thrombospondin; CD, Cluster of differentiation.

CD36 receptors protein also showed the same tendency of significantly higher expression in the CL groups other than the early stages ( $p<0.05$; Fig. 2D). Overall, the expression of the TSPs and their receptor system was confined to the late and regressed stage of CL, while the early stages showed weak expression.

\section{Immunohistochemistry of CL}

Immunohistochemistry of late stage CL (Fig. 3-5) revealed that the TSPs and their receptor were localized with intense fluorescence. The immunofluorescence of all the TSPs and their receptors was restricted to the cytoplasm. The immunofluorescent staining of TSP1 (Fig. 3A-D), TSP2 (Fig. 4A-D) and CD36 (Fig. 5A-D) in the late stages of CL was consistent by evidence of fluorescence signal. 


\section{Cellular Physiology Cell Physiol Biochem 2019;52:532-552

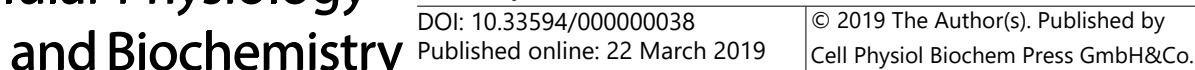

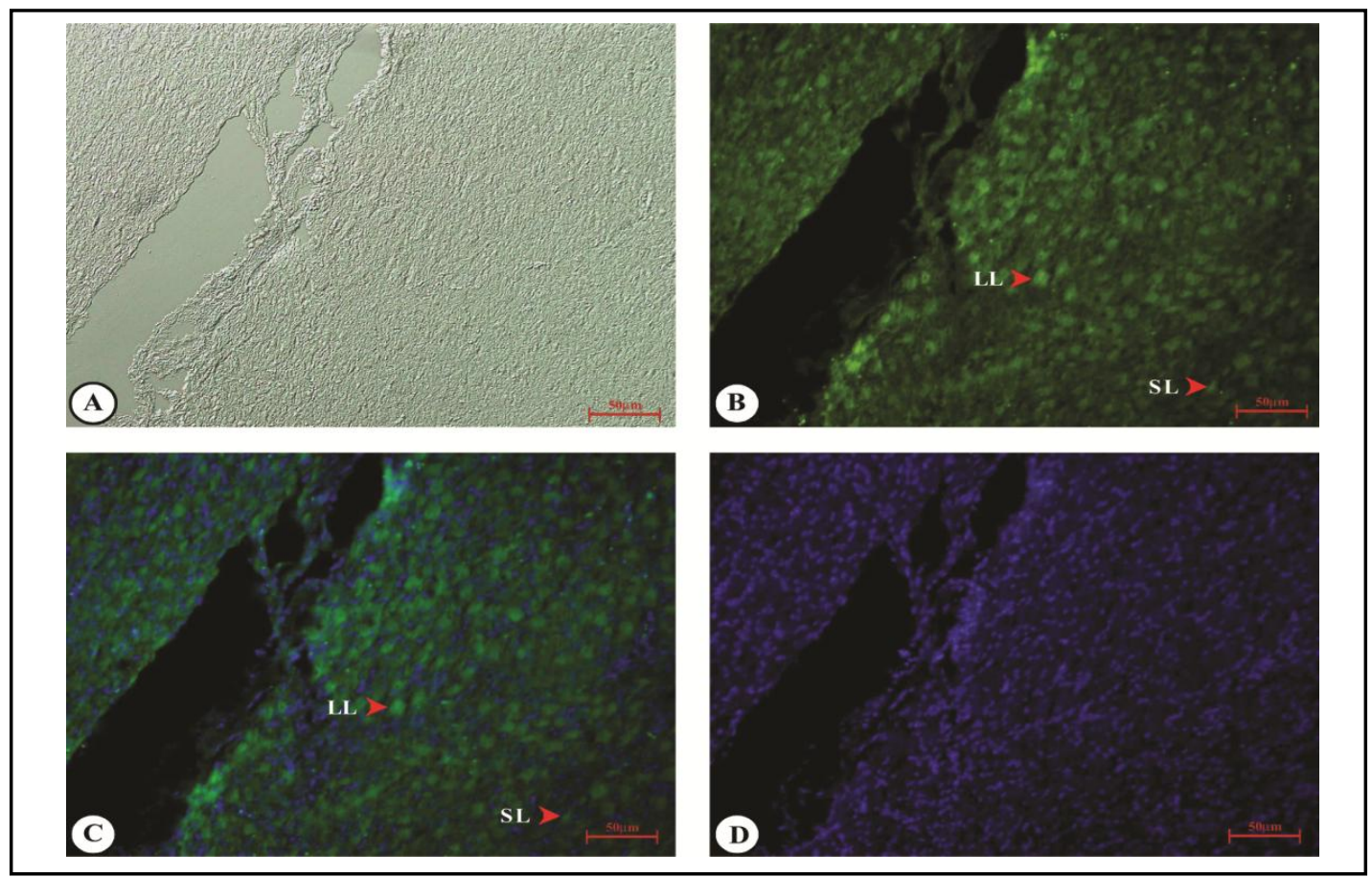

Fig. 3. Immunohistochemical localization of TSP1 in the late CL stage of riverine buffalo. The $5 \mu \mathrm{m}$ thick sections of CL were deparaffinised and rehydrated, followed by antigen retrieval. Primary TSP1 antibody was used at 1:200 while the FITC was used at 1:500. DAPI was used to counter stain nucleus. Fluorescent signals were captured by microscopy (Carl Zeiss Micro Imaging $\mathrm{GmbH}$ ). Representative images from (A) bright field, (B) through (C) indicate intense immunoreactivity in late stages of CL progression which was localized predominantly in the cytoplasm of luteal cells. No primary antibody was used in the negative control (D). Scale bar $=50 \mu \mathrm{m}$. Abbreviations: LL, Large luteal cell; SL, Small luteal cell; FITC, Fluorescein isothiocyanate; DAPI, 40,6-diamidino-2-phenylindole dihydrochloride.

\section{Effects of Thrombospondin1 (TSP1) on Luteal Cell Viability and Function}

To determine the effect of TSP1 on CL, in vitro stimulation of the primary luteal cell culture derived from the late stage CL of buffalo was established. To determine whether TSP1 influences the viability of buffalo luteal cells, an MTT assay was performed to assess the dose-dependent effect of TSP1. The MTT assay revealed a significant decrease in the number of viable cells in a dose dependent manner over a period of 72 hours. Interestingly, at the $500 \mathrm{ng} / \mathrm{ml}$ dose of TSP1, cell viability reached less than $50 \%$ of untreated control cells $(p<0.05$; Fig. 6$)$. Similarly, the transcripts of angiogenic growth factors mainly VEGF and FGF2 showed significant down regulation in a time dependent manner $(p<0.05$; Fig. 7A \& 7B). Of the three TSP1 concentrations tested, both $500 \mathrm{ng} / \mathrm{ml}$ and $100 \mathrm{ng} / \mathrm{ml}$ down regulated the expression of VEGF and FGF2 at 72 hour culture as compared to other doses except at $24 \mathrm{hr}$ of culture. However, significant upregulation of the apoptotic gene Caspase 3 was observed at the 72 hour culture with TSP 1 at $500 \mathrm{ng} / \mathrm{ml}$ dose $(p<0.05$; Fig. $7 \mathrm{C})$. A significant dose effect of TSP1 over a period of $72 \mathrm{~h}$ for $\mathrm{P}_{4}$ synthesis was observed and at $500 \mathrm{ng} / \mathrm{ml}$, TSP1 showed the lowest value for progesterone $\left(\mathrm{P}_{4}\right)$ which correlated with the percentage of viable luteal cells ( $p<0.05$; Fig. 8$)$ and upregulation of apoptotic gene after 72 hour of culture. 


\section{Cellular Physiology \begin{tabular}{ll|l} 
and Biochemistry & $\begin{array}{l}\text { DOI: 10.33594/000000038 } \\
\text { Published online: 22 March } 2019\end{array}$ & $\begin{array}{l}\text { C } 2019 \text { The Author(s). Published by } \\
\text { Cell Physiol Biochem Press GmbH\&Co. KG }\end{array}$
\end{tabular}

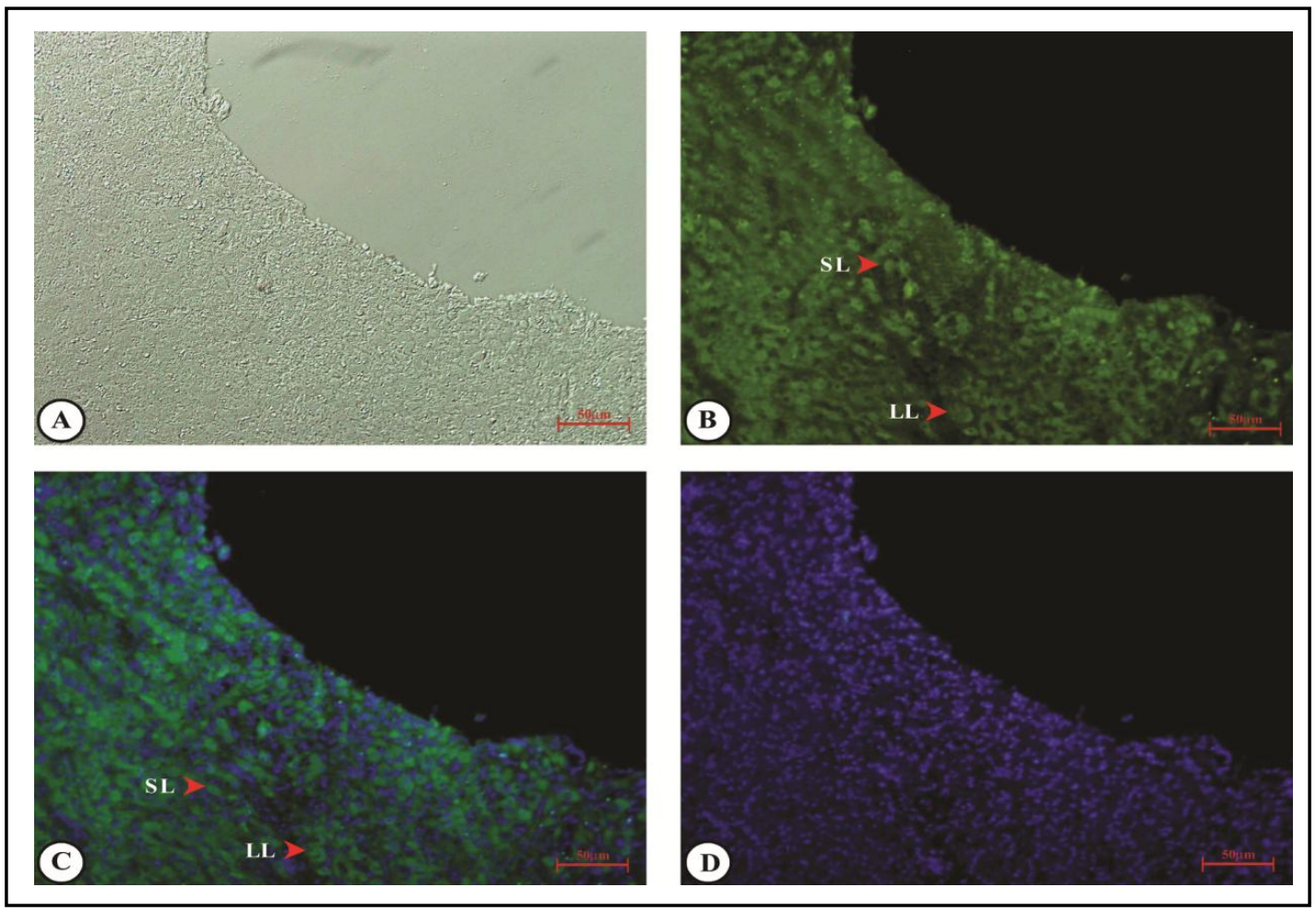

Fig. 4. Immunohistochemical localization of TSP 2 in the late CL stage of riverine buffalo. The $5 \mu \mathrm{m}$ thick sections of CL were deparaffinised and rehydrated, followed by antigen retrieval. Primary TSP1 antibody was used at 1:200 while the FITC was used at 1:500. DAPI was used to counter stain nucleus. Fluorescent signals were captured by microscopy (Carl Zeiss Micro Imaging GmbH). Representative images from (A) bright field, (B) through (C) indicate intense immunoreactivity in late stages of CL which was localized predominantly in the cytoplasm of luteal cells. No primary antibody was used in the negative control (D). Scale bar $=50 \mu \mathrm{m}$. Abbreviations: LL, Large luteal cell; SL, Small luteal cell; FITC, Fluorescein isothiocyanate; DAPI, 40,6-diamidino-2-phenylindole dihydrochloride.

\section{Determining the effect of knocking out of the endogenous TSP1 on luteal cell viability and function}

CRISPR/Cas9 mediated genomic editing technology was used to knockout the Thrombospondin 1 (TSP1) gene to better understand luteal cell viability and function. The TSP1 gene specific guide RNA was designed using available software in silico (Table 1) and in vitro SgRNA was synthesized in laboratory as per manufacturer's instruction and was transfected along with Cas9 into luteal cells @ 30-70\% confluency. The confirmation of TSP1 knockout was validated by T7E1 assay using GeneArt Genomic Cleavage Detection Kit. The efficiency of TSP1 knockout was 75.4\% (Fig. 9) and knocked out cells were then used for viability and mRNA expression analysis.

The MTT study revealed no significant difference in viability between control and TSP1 knocked out cells as there were almost $84 \%$ viable luteal cells after knocking out of the TSP1 endogenous protein ( $p>0.05$; Fig. 6 ). To determine whether knocking out of TSP1 reduced the viability of luteal cells or not, we performed Annexin V-FITC/PI analysis. After $72 \mathrm{hr}$ incubation, less fluorescent signal was detected in knockout luteal cells compared to control group (Fig. 10) under Axio Observer.Z1 (Carl Zeiss Micro Imaging GmbH, Germany) microscope. Again mRNA expression levels of VEGF, FGF2 and Caspase 3 was measured to elucidate the functional role of TSP1 after knocking out TSP1 expression. Interestingly, both VEGF and FGF2 showed significantly increased expression $(p<0.05$; Fig. 11) in knocked out cells however, Caspase 3 expression was slightly down regulated which was consistent with both MTT assay and Annexin V assays. 


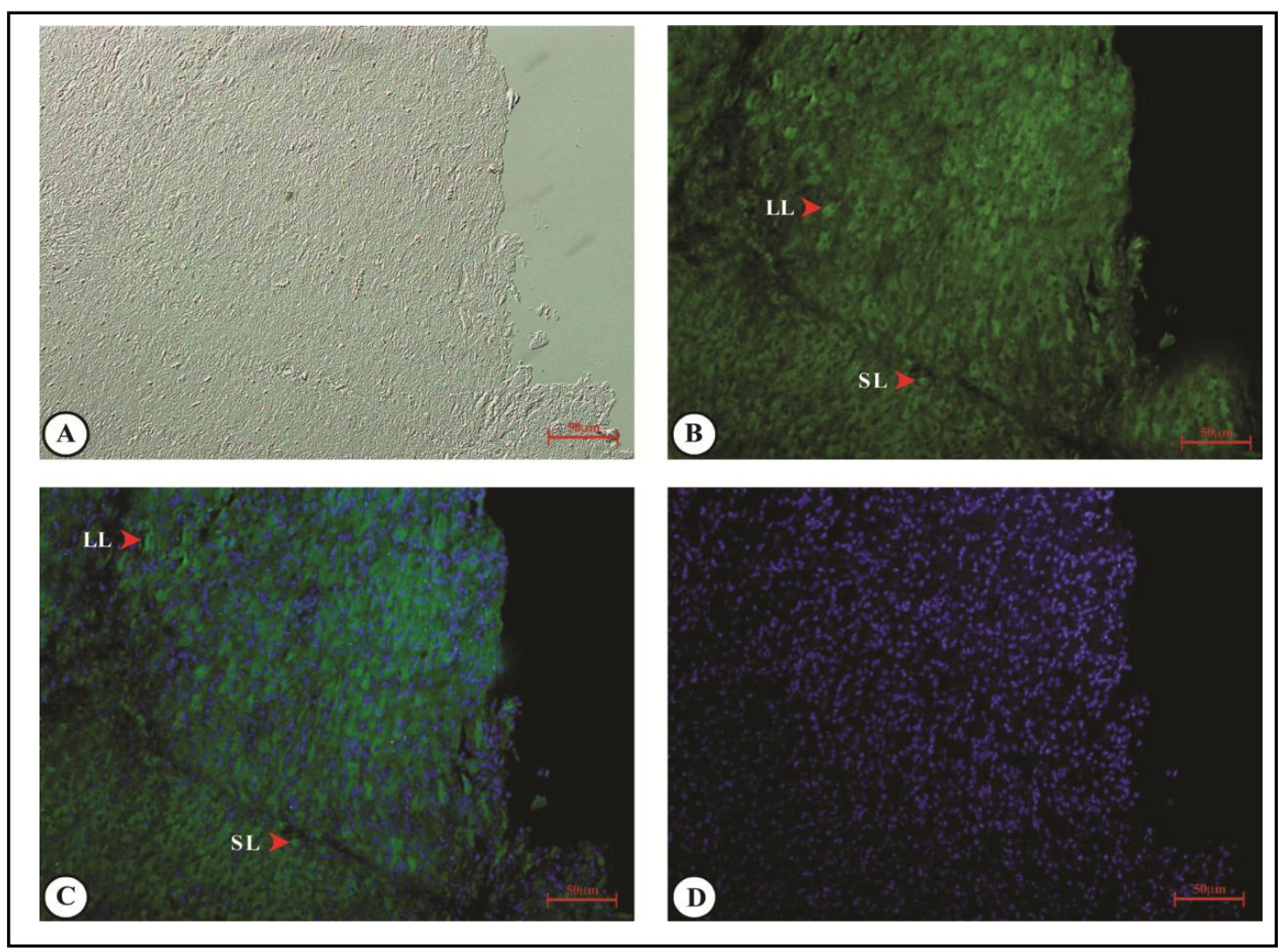

Fig. 5. Immunohistochemical localization of CD36 in the late CL stage of riverine buffalo. The $5 \mu \mathrm{m}$ thick sections of CL were deparaffinised and rehydrated, followed by antigen retrieval. Primary TSP1 antibody was used at 1:200 while the FITC was used at 1:500. DAPI was used to counterstain nucleus. Fluorescent signals were captured by microscopy (Carl Zeiss Micro Imaging $\mathrm{GmbH}$ ). Representative images from (A) bright field, (B) through (C) indicate intense immunoreactivity in late stages of CL which was localized predominantly in the cytoplasm of luteal cells. No primary antibody was used in the negative control (D). Scale bar $=50 \mu \mathrm{m}$. Abbreviations: LL, Large luteal cell; SL, Small luteal cell; FITC, Fluorescein isothiocyanate; DAPI, 40, 6-diamidino-2-phenylindole dihydrochloride.

Fig. 6. Demonstration of percentage viable luteal cells treated with increasing concentrations of Thrombospondin 1 (50-500 $\mathrm{ng} / \mathrm{ml}$ ) and also for TSP1 knockout luteal cells for 72 hour at $37^{\circ} \mathrm{C}$. MTT was added at $5 \mathrm{mg} / \mathrm{ml}$ to each well and further incubated for $4 \mathrm{~h}$ and absorbance was measured at $450 \mathrm{~nm}$ using a 96-plate reader to measure cell proliferation. Abbreviation: MTT, 3-(4,5-dimethylthiazole-2-yl))-2-5-diphenyltetrazolium bromide; TSP, Thrombospondin; TSP1-KO, TSP1 knockout.

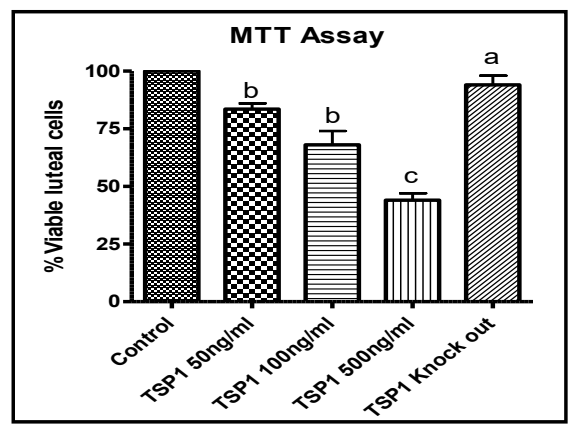

\section{Demonstrating the effect of $\mathrm{LH}$ and $\mathrm{PGF}_{2} \alpha$ hormone on expression of Thrombospondin system}

There were no significant difference in the expression pattern of TSPs (Fig. 12A, B) in cultured luteal cells with different doses of LH at various time interval in vitro; however the transcripts of receptor CD36 and pro-apoptotic Caspase 3 significantly decremented $(p<0.05)$ with $100 \mathrm{ng} / \mathrm{ml} \mathrm{LH}$ compared to control at 72 hour of culture (Fig. 12C, D). An interesting expression pattern of thrombospondins and their receptor for luteal function, 


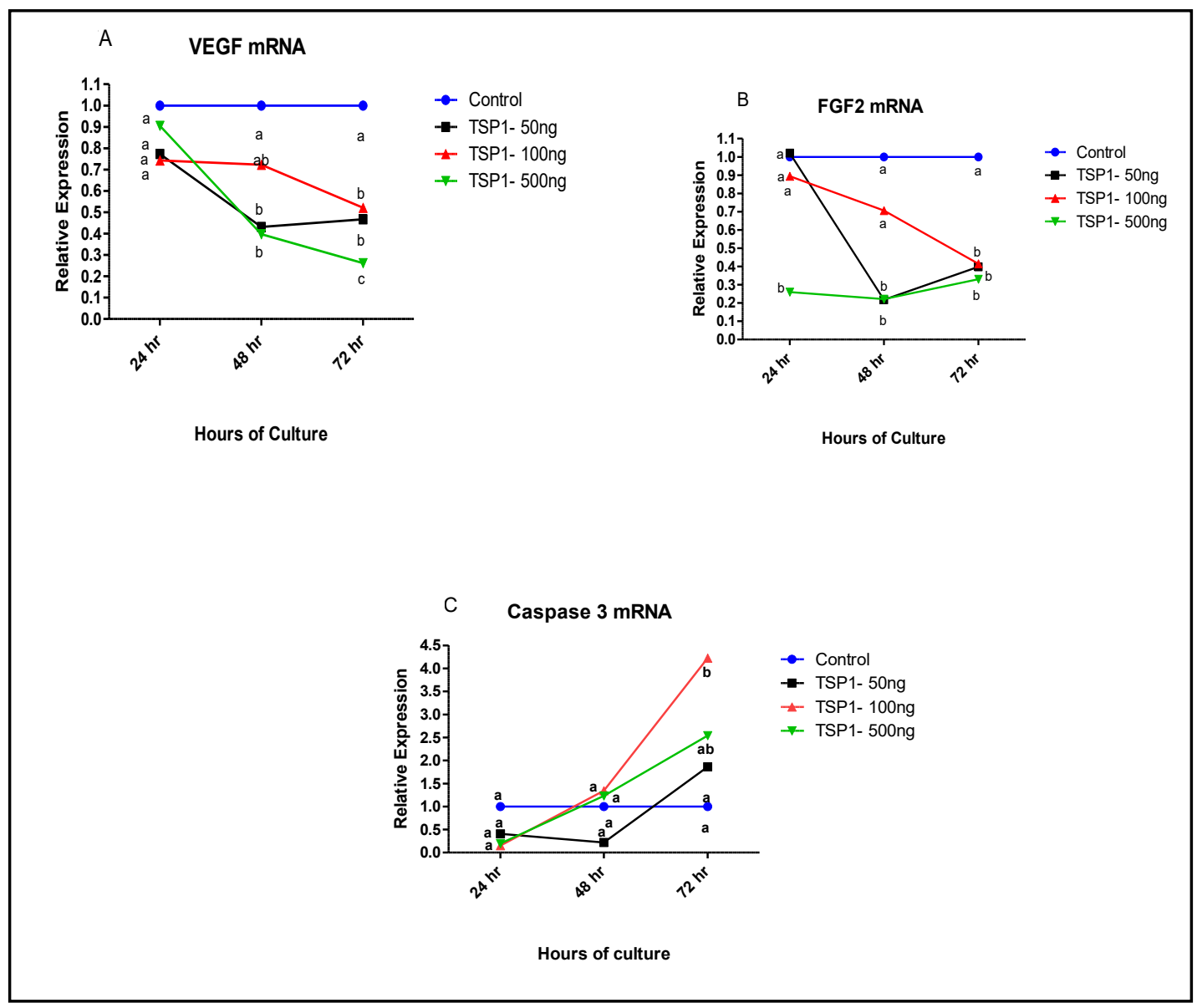

Fig. 7. Effect of TSP1 on mRNA expression of VEGF (A), FGF2 (B) and Caspase 3 (C) in in-vitro luteal cell culture. Briefly, cells isolated from late stage CL (Days 11-16) were stimulated with increasing concentrations of TSP1 $(0,50,100$, and $500 \mathrm{ng} / \mathrm{ml})$ at $75-80 \%$ confluency over a period of 24,48 and $72 \mathrm{~h}$ ( $\mathrm{n}=3 /$ condition). Cells lysate was used for the extraction of total RNA and cDNA preparation. Two-way ANOVA with Tukey's HSD was performed to find the effect of concentration and time on the mRNA expression of VEGF, FGF2 \& Caspase. Each point in the line chart indicates Mean \pm SEM. The different superscripts denote statistical significance $(\mathrm{p}<0.05)$. Abbreviations: TSP1, Thrombospondin1; mRNA, Messenger RNA; VEGF, Vascular Endothelial Growth Factor, FGF, Follicular Growth Factor.

Fig. 8. Different concentration dependent effects of TSP1 on P4 production in the bubaline luteal cells cultured in vitro at 72 hour of culture. Graph also depicting the amount of progesterone in spent media of TSP1 knocked out luteal cells after 72 hour of culture. Production of P4 in the supernatant was assayed by RIA. One-way ANOVA with Tukey's HSD test was used to find the effect of concentration and time on the dependent variables like $\mathrm{P} 4$. Each point in the line chart indicates Mean \pm SEM at 95\% significance $(\mathrm{p}<0.05)$. Abbreviations: TSP, Thrombospondin; CL, Corpus luteum; P4, Progesterone; TSP1-KO, TSP1 knockout.

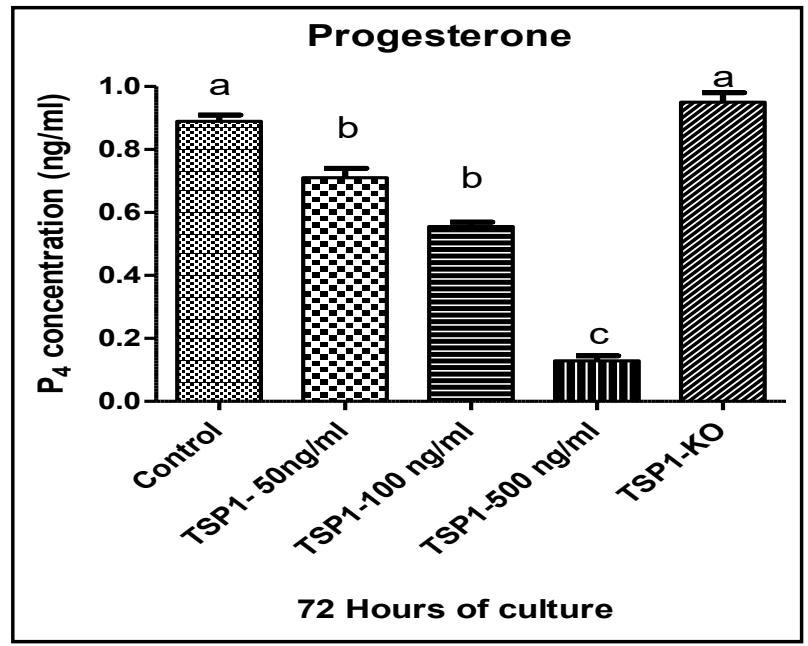


Fig. 9. Gel image of Genomic Cleavage Detection Assay of luteal cells transfected with components of CRISPR/Cas9 system for knocking out TSP1 using Lipofectamine $\AA$ 2000. Lane 1: negative control sample for TSP1 gene. Lane 2: Showing parent and both the cleaved bands. The above samples were PCR amplified using the same set of primers flanking the region of interest. After re-annealing, samples were treated with and without Detection Enzyme and run on a $2 \%$ E-Gel® EX Gel. Lane M: 100 bp DNA
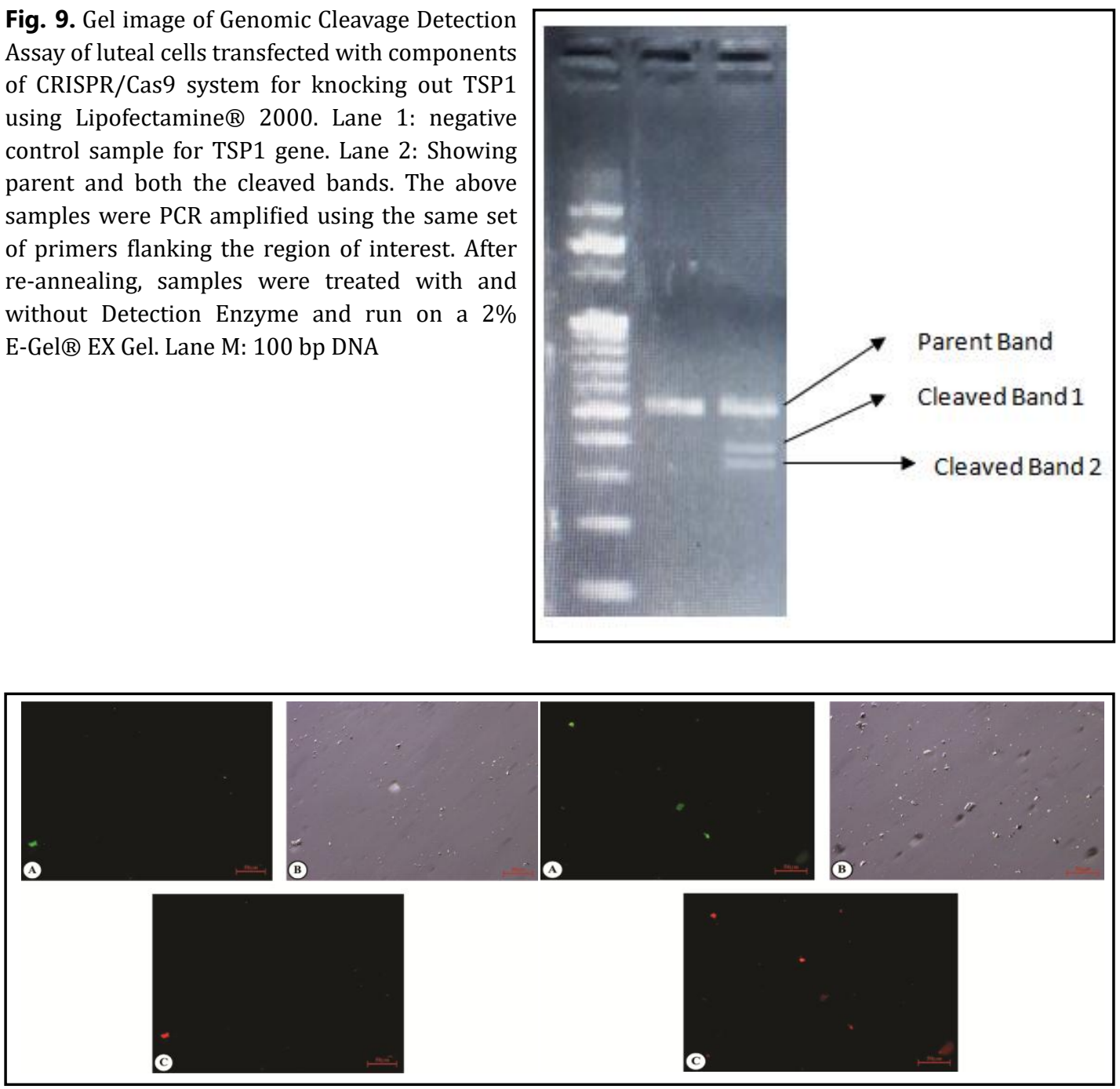

Fig. 10. Images of TSP1KO (Left) and Wild luteal (Right) cells showing signal for FITC Annexin (A) and PI (C). Both the group of cells was cultured for 72 hour followed by trypsinization and treatment with Annexin $\mathrm{V}$ apoptosis detection and Propidium iodide dye.After incubation Fluorescent signals were detected by Axio Observer.Z1 microscope. Image (B) indicates cells under bright field image.

Fig. 11. mRNA expression of VEGF, FGF2 and Caspase 3 in both wild/ control and TSP1 knockout (KO) luteal cells. CRISPR-Cas9 mediated gnomic editing technology was used to produce TSP1 knockout luteal cells. Cells from both the groups were cultured up to 75$80 \%$ confluency over a period of $72 \mathrm{~h}$ ( $\mathrm{n}=3 /$ condition). Cells lysate was used for the extraction of total RNA and cDNA preparation. Twoway ANOVA with Tukey's HSD

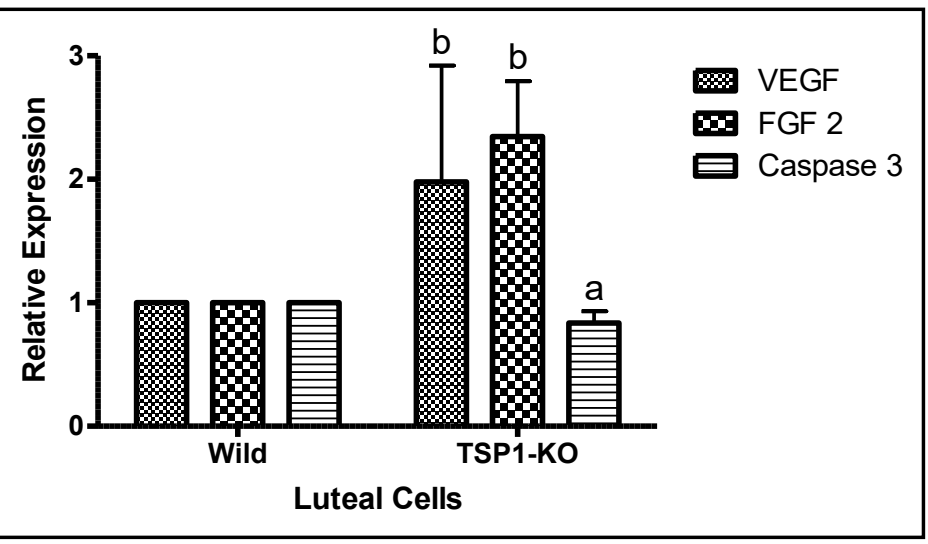
was done to analyse the mRNA expression of VEGF, FGF2 \& Caspase. Each point in the line chart indicates Mean \pm SEM. The different superscripts denote statistical significance $(\mathrm{p}<0.05)$. 


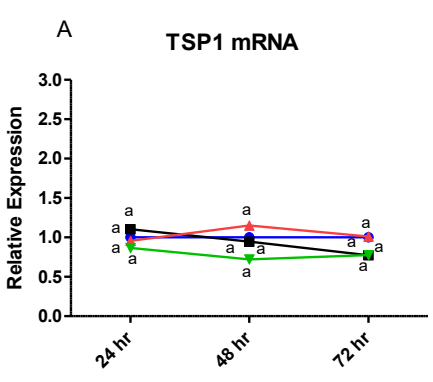

Hours of culture

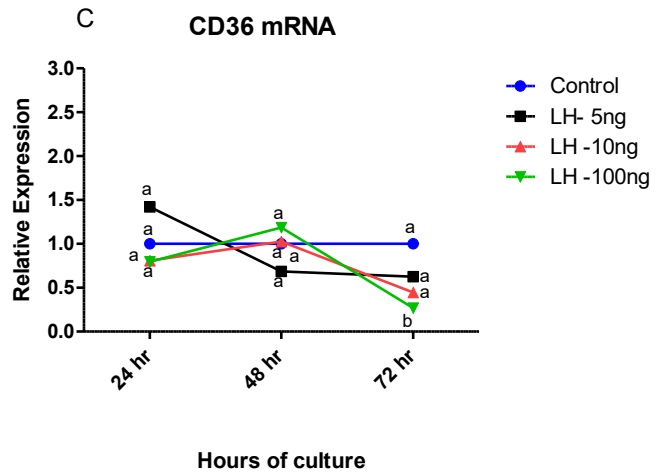

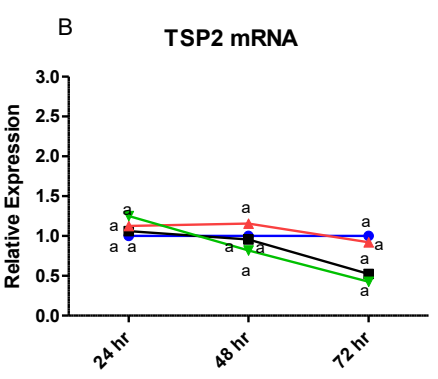

$\rightarrow$ Control

- LH- $5 \mathrm{ng}$

$\rightarrow$ LH $-10 \mathrm{ng}$
$\rightarrow$ LH $-100 n g$

$\rightarrow$ LH- 5 ng

\pm LH- 10ng

$\rightarrow$ LH-100ng

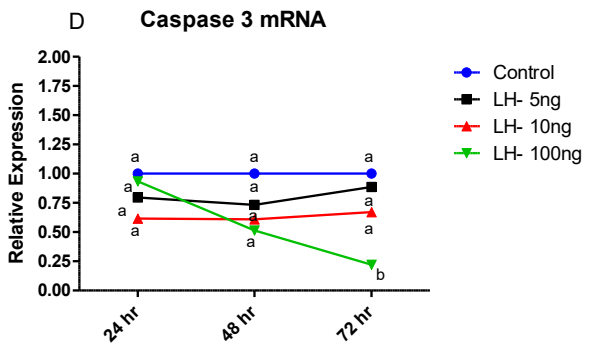

Hours of Culture

Fig. 12. Effect of Gonadotrophin LH on luteal cells to determine its effect on TSP system in vitro luteal cell culture. Luteal cells were stimulated with increasing concentrations of $\mathrm{LH}(0,5,10$, and $100 \mathrm{ng} / \mathrm{ml})$ at 75$80 \%$ confluency over a period of 24,48 and $72 \mathrm{~h}$ ( $\mathrm{n}=3$ /condition). Cells lysate was used for the extraction of total RNA and cDNA preparation. Two-way ANOVA with Tukey's HSD was done to find the effect of LH concentration and time on the mRNA expression of TSP and its receptor system. Each point in the line chart indicates Mean \pm SEM. The different superscripts denotes statistical significance $(\mathrm{p}<0.05)$. Abbreviations: TSP1, Thrombospondin1; mRNA, Messenger RNA; TSP, Thrombospondin; CD, cluster of differentiation.

especially related to luteolysis was observed after in vitro stimulation of luteal cell culture with different doses of $\mathrm{PGF}_{2} \alpha$ for various period of time. TSP1, TSP2 and CD36 transcripts showed a significant increase with respect to time and concentration, especially at 72 hours with the highest dose $\left(10 \mu \mathrm{g} / \mathrm{ml}\right.$ media) of $\mathrm{PGF}_{2} \alpha$ analogue $(p<0.05$; Fig. $13 \mathrm{~A}-\mathrm{C})$. The effect of $\mathrm{PGF}_{2} \alpha$ at $10 \mu \mathrm{g} / \mathrm{ml}$ also revealed a highly significant increase in the apoptotic Caspase 3 at 72 hour of culture as compared to other doses at 24 and $48 \mathrm{hr}$ of culture ( $p<0.05$; Fig. $13 \mathrm{D}$ ).

Transcriptional interaction of Thrombospondin with angiogenic growth factor (VEGF) and FGF2 in vitro luteal cell culture system

This in vitro study showed a remarkable inverse and significantly regulated expression of thrombospondins and its receptor on luteal cell culture system with increasing concentration of $\mathrm{VEGF}$ over a period of time in contrast to $\mathrm{PGF}_{2} \alpha$. Of the three concentrations tested, VEGF at $100 \mathrm{ng} / \mathrm{ml}$ showed a highly significant down regulation of both TSPs and CD36 at $72 \mathrm{hr}$ of culture ( $p>0.05$; Fig. $14 \mathrm{~A}-\mathrm{C}$ ) as compared to other doses at both 24 and 48 hour. The expression of Caspase 3 is also consistent with the expression of TSPs, which showed significant down regulation $(p<0.05$; Fig. $14 \mathrm{D})$ at 72 hour of culture with highest dose of VEGF. The relative fold change in TSP transcripts and its receptor system in late stage culture luteal cells stimulated with various doses of FGF2 in vitro are given in Fig. 15. 


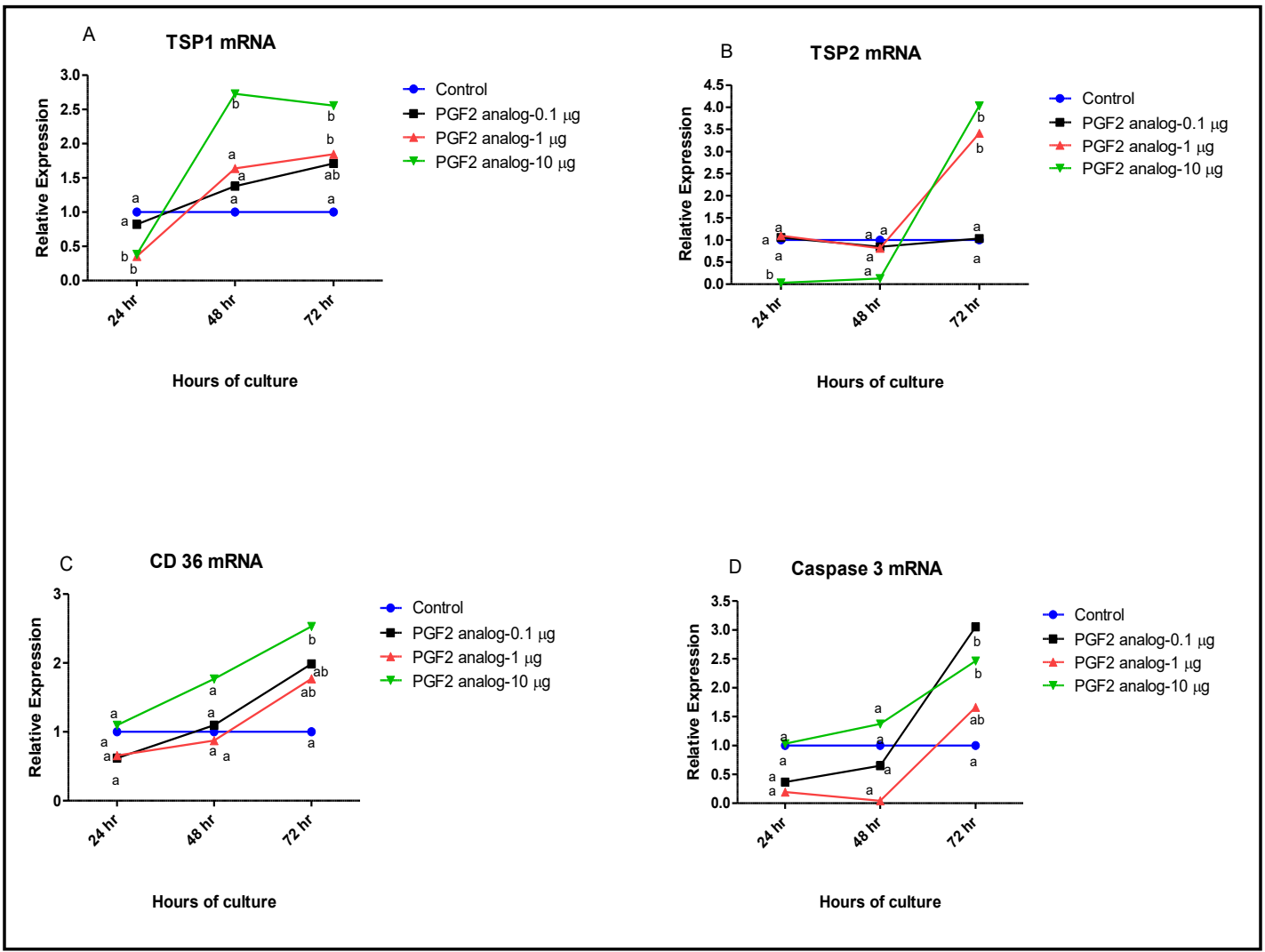

Fig. 13. Effect of PGF $2 \alpha$ on luteal cells to determine its effect on TSP system in vitro luteal cell culture. Briefly, isolated luteal cells were stimulated with increasing concentrations of PGF $2 \alpha(0,0.1,1$, and $10 \mu \mathrm{g} /$ $\mathrm{ml}$ ) at $75-80 \%$ confluency over a period of 24,48 and $72 \mathrm{~h}(\mathrm{n}=3 /$ condition). Cells lysate was used for the extraction of total RNA and cDNA preparation. Two-way ANOVA with Tukey's HSD was done to find the effect of PGF $2 \alpha$ concentration and time on the mRNA expression of TSP and its receptor system. Each point in the line chart indicates Mean \pm SEM. The different superscripts denote statistical significance $(p<$ 0.05). Abbreviations: TSP1, Thrombospondin1; mRNA, Messenger RNA; TSP, Thrombospondin; CD, cluster of differentiation; PGF2 $\alpha$, Prostaglandin F2 $\alpha$.

Luteal cells treated with FGF2 are based on our earlier findings in bovine luteal endothelial cells [18]. We have observed significant $(p<0.05)$ down regulation of TSPs and Caspase 3 transcripts (Fig. 15 A, B \& D) at 48 and 72 hour culture with highest dose of FGF2 (50ng/ $\mathrm{ml}$ ) as compare to control and 24 hour culture group, however, no significant difference was observed with CD36 mRNA expression (Fig. 15 C).

\section{Discussion}

The mammalian ovary has special characteristics wherein it undergoes rapid cyclical remodeling throughout the reproductive cycle that involves numerous tightly controlled cellular and hormonal events $[1,19]$. The different phases of the CL life cycle are marked by dynamic changes in vasculature, luteal cell population, and later in the cycle, luteal demise which is characterized by cessation of steroid production, angio-regression, and apoptotic cell death. The relevance of thrombospondins to ovarian physiology has been demonstrated in the present study in which it was observed that TSPs and their receptors was significantly induced in various stages of cyclic corpus luteum in water buffalo. We identified novel stage specific expression of members of the TSP family in the bubaline ovary during CL development. In the present investigation, the highest expression of both TSPs and their 


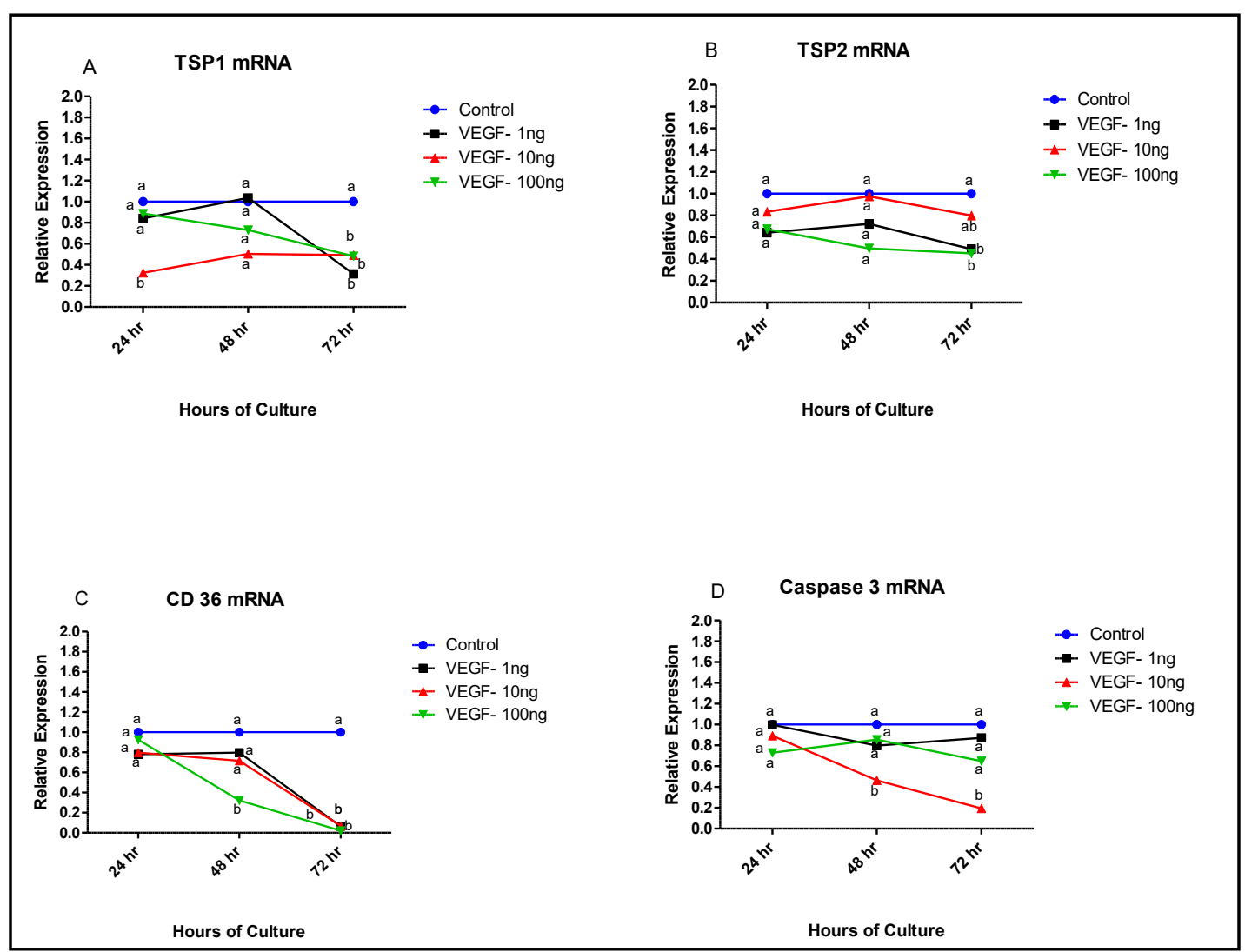

Fig. 14. Effect of VEGF on luteal cells to determine its effect on TSP system in vitro luteal cell culture. Briefly, isolated cells of CL were stimulated with increasing concentrations of VEGF $(0,1,10$, and $100 \mathrm{ng} / \mathrm{ml})$ at $75-$ $80 \%$ confluency over a period of 24,48 and $72 \mathrm{~h}$ ( $\mathrm{n}=3$ /condition). Cells lysate was used for the extraction of total RNA and cDNA preparation. Two-way ANOVA with Tukey's HSD was done to find the effect of VEGF concentration and time on the mRNA expression of TSP and its receptor system. Each point in the line chart indicates Mean \pm SEM. The different superscripts denotes statistical significance $(\mathrm{p}<0.05)$. Abbreviations: TSP1, Thrombospondin1; mRNA, Messenger RNA; TSP, Thrombospondin; CD, cluster of differentiation.

receptors transcripts in late and regressed stage of CL is consistent with the findings of immunoblot (Fig. 2A and B, C) and immunohistochemistry experiments (Fig. 3, 4). Our results on TSPs mRNA expression are in agreement with earlier reports in cattle CL [20]. Thrombospondins have also been found to be expressed and localized in human GC and large luteal cells [21]. Our findings are also in accordance with the previous studies in which TSPs and their receptors CD36 and CD47 are found to be expressed and localized in the luteal cell and endothelial cell of bovine ovaries [9]. The expression pattern of CD36 receptor in bubaline CL as observed in the present study is in conformity with the findings of maximum expression in the corpora lutea during regression in cow [20]. Increased expression of CD47 has been reported to correlate with increased endothelial cell apoptosis. TSP1 binds CD47 in a high-affinity manner and inhibits NO-cGMP signaling, thus act as a potent inhibitor of endothelial cells proliferation, adhesion, and migration [22-23]. The upregulation of TSPs in late and regressed CL might be to induce the luteolysis of the $\mathrm{PGF}_{2} \alpha$ primed CL by disrupting angiogenesis and activating apoptosis mediated cell lysis [24]. Therefore, at the end of estrous cycle, thrombospondins might be acting directly through its receptors to affect angiogenesis and stimulate the apoptotic signaling cascade, ultimately leading to luteal regression [25].

TSP1 is a multimodular protein and its anti-angiogenic activity is exerted through multiple mechanisms involving different domains [25]. Thrombospondin1 (TSP1) is one of the most important endogenous anti-angiogenic molecules that bind and sequester angiogenic growth factors (AGFs) in the extracellular environment. In the present investigation, we have 


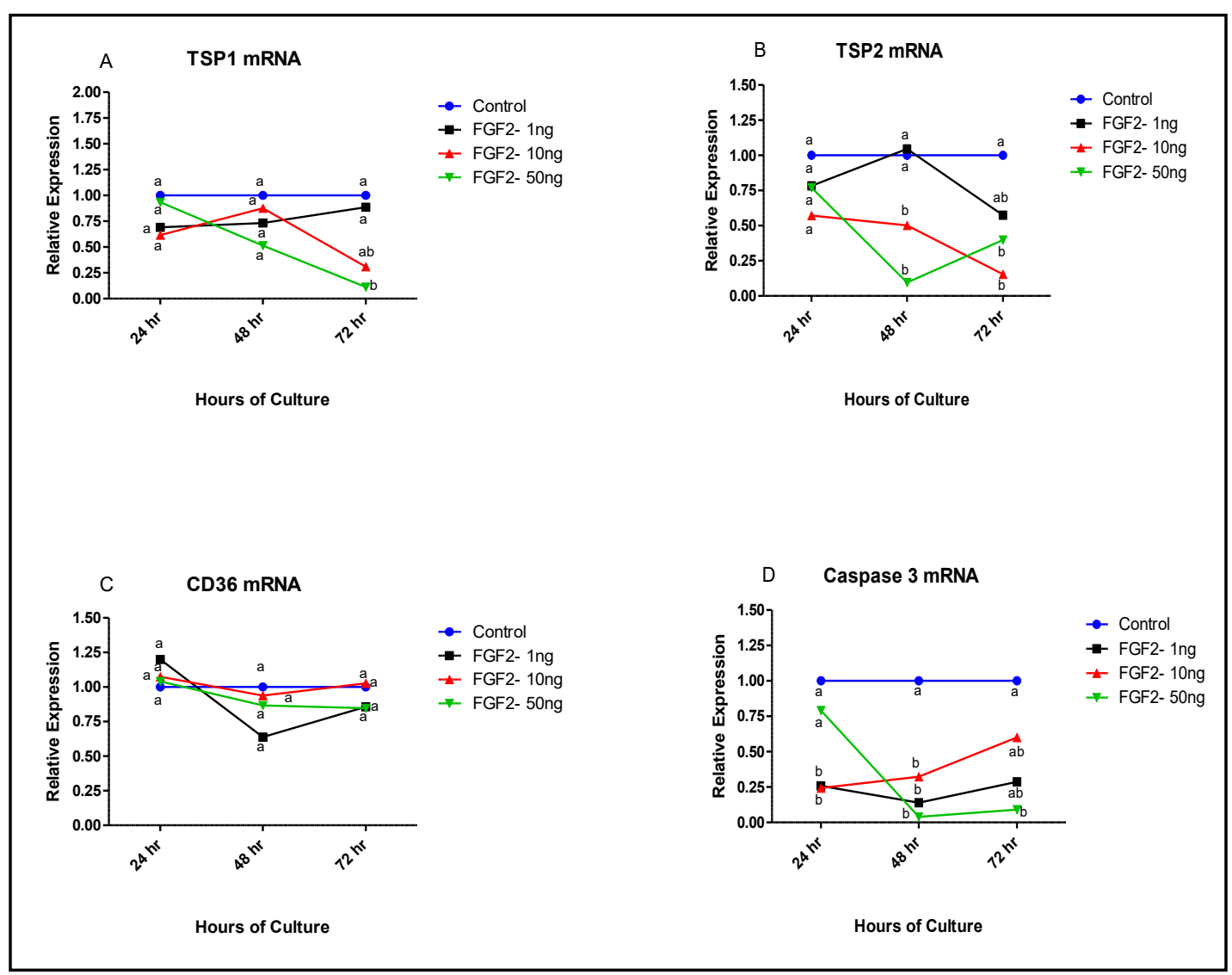

Fig. 15. Effect of FGF2 on luteal cells to determine its effect on TSP system in vitro luteal cell culture. Briefly, isolated luteal cells were stimulated with increasing concentrations of FGF2 $(0,1,10$, and $50 \mathrm{ng} / \mathrm{ml})$ at $75-$ $80 \%$ confluency over a period of 24,48 and $72 \mathrm{~h}$ ( $\mathrm{n}=3$ /condition). Cells lysate was used for the extraction of total RNA and cDNA preparation. Two-way ANOVA with Tukey's HSD was done to find the effect of FGF2 concentration and time on the mRNA expression of TSP and its receptor system. Each point in the line chart indicates Mean \pm SEM. The different superscripts denotes statistical significance $(\mathrm{p}<0.05)$. Abbreviations: TSP1, Thrombospondin1; mRNA, Messenger RNA; TSP, Thrombospondin; CD, cluster of differentiation.

observed that the TSP1 dose time dependently abrogated both VEGF and FGF2 expression, decreased luteal cell viability and promoted induction of Caspase 3 in cultured luteal cells. Our findings are attuned with report that TSP1 could be inducing apoptosis via the inhibition of the survival promoting effects of VEGF [26]. In another study, Type III repeats of TSP1 bind and sequestrate FGF2. Using luteal endothelial cells, it was found that TSP1 inhibited FGF2 induced proliferations and migration in vitro [27]. Zalmen et al. [24] reported that TSP1 inhibited FGF2 induced proliferation and migration of luteal endothelial cells (LEC) and when both were added exogenously to cultures of LEC they mutually inhibit their expression. Greenaway et al. [28] also showed that TSP1 treatment decreased VEGF levels and rendered cells more susceptible to TNF- $\alpha$ induced apoptosis in rat ovary. The significant reduction of angiogenic growth factors may be due to the scavenging effect of TSP1 which act in a paracrine manner to reduce the bioavailability and angiogenic support in CL at the time of demise [24, 28].

The decreasing trend of progesterone concentration by TSP1 in a dose dependent manner that was observed in the present study might be due to the reduction in luteal cell number and inhibitory effect on progesterone biosynthetic pathway. Recently it was reported that Thrombospondin 1 reduces viable cell numbers and induce apoptotic cell death in luteinized endothelial cells as evidenced by nuclear fragmentation [10]. Earlier reports have shown that TSP1 promotes follicular atresia in vitro by directly inducing apoptosis of granulosa cells 
[26]. In order to validate the transcriptional and functional regulation of thrombospondins and their interrelationship with angiogenic growth factors we have attempted to knockout TSP1 in luteal cells of buffalo by a very efficient CRISPR/Cas9 genome editing tool and all the effects of TSP1 on cultured luteal cells were found to be reversed. It was reported in a previous study that knockdown of TSP1 in vitro and in vivo resulted in an increase in VEGF levels in the ovaries of TSP1 null mice [28]. In another study, TSP1-null mice demonstrated significantly increased retinal vascularization due to higher level of VEGF expression [29]. The knockdown of TSP1 in luteal endothelial and granulosa cells by siRNA resulted in an increase in FGF2 mRNA level in cow [24]. Our knockout experiment supported the hypothesis that there exists a delicate balance between thrombospondins and other angiogenic growth factors like VEGF and FGF2 for proper luteal cell function and development in buffalo.

Luteinizing signals such as LH given in a supra-physiological dose, intended to activate IGF-1 receptors ultimately reduces the TSPs and their receptors [30]. These findings imply that the process of luteinization favors reduction of TSP expression and function [13]. In the present investigation, the reduced expression of the TSP family along with their receptors induced by LH could be due to the fact that luteinizing signal of gonadotrophin might have blocked the signals for activation of thrombospondins thus blocking the ability to efficiently establish the steroidogenic activity of CL. Our findings that PGF $\alpha$ upregulated the expression of TSP system are in concurrence with previous reports, where PG treatment in the responsive CL, strongly upregulated thrombospondins and CD36 in bovine [24]. In another study, after induced luteolysis, the mRNA expression of TSPs and CD36 in CL were significantly increased after 24 and 48 hour of PGF injection respectively [20]. TSP1 can also activate latent TGFB1, which induces the disassembly of luteal capillary-like structures and disrupt the angiogenic potential of microvascular endothelial cells of bovine CL [31]. This study suggests that a functional relationship does exist between $\mathrm{PGF}_{2} \alpha$ and thrombospondin mediated vascular disruption of CLs that advance towards luteolysis.

Several works have been conducted so far to develop the functional relationship between pro-angiogenic growth factors VEGF and FGF2 with thrombospondins in various species of mammals. The bovine CL produces various angiogenic growth factors including VEGF, a potent mitogen for endothelial cells; stimulator of vascular permeability; strong luteotrophic factor of CL and indeed VEGF can stimulate progesterone secretion from bovine CL [32]. Therefore, we have attempted to mimic an in vivo situation wherein luteal cells were treated with VEGF and FGF2 to demonstrate their effect on thrombospondin system in buffalo CL. It was observed that both VEGF and FGF2 have down regulated TSPs, CD36 and Caspase 3 transcripts. Data from an earlier report show that a decrease in TSP content and expression in medium and large bovine follicles compared with small follicles is associated with a concomitant increase in VEGF expression [9]. An inverse relationship has also been reported between VEGF and members of the THBS family in different physiological and pathological conditions [33]. In another study, a remarkable inverse expression pattern of thrombospondins relative to VEGF expression in ovarian follicles and corpora lutea in bovine was noticed [32]. VEGF might have suppressed the activation of thrombospondin system during CL development for its proper maturation and luteotropic function. Results of another study from our lab indicated that a higher concentration of FGF2 played a significant role in luteal steroidogenesis and up-regulated the expression of steroidogenic pathway intermediates in buffalo CL [5]. Moreover, neutralization of FGF2 by injecting FGF2 antibody leads to a reduction in luteal growth and steroidogenesis in bovine CL [34] and FGF2 was also able to partially abrogate TSP1-induced Caspase 3 activation [13]. Recently, it has been shown that immunoneutralization of FGF2 suppressed CL growth and progesterone production in the cow [35]. In our study we noticed that VEGF and FGF2 dose dependently down regulated TSP expression in cultured luteal cells. Therefore, the role of VEGF and FGF2 in initiation of angiogenesis suggests that, they are playing a role in the down regulation of the anti-angiogenic factors, TSPs during luteal development in buffalo. 


\section{\begin{tabular}{ll} 
Cellular Physiology & Cell Physiol Biochem 2019;52:532-552 \\
\hline DOl: 10.33594/000000038 & 2019 The Author(s). Published by \\
\cline { 2 - 2 }
\end{tabular} \begin{tabular}{l|l|l} 
and Biochemistry & $\begin{array}{l}\text { DOI: } 10.33594 / 000000038 \\
\text { Published online: } 22 \text { March } 2019\end{array}$ & $\begin{array}{l}\text { c } 2019 \text { The Author(s). Published by } \\
\text { Cell Physiol Biochem Press GmbH\&Co. KG }\end{array}$ \\
\cline { 2 - 3 }
\end{tabular}}

\section{Conclusion}

In conclusion, the present study demonstrates the co-expression of thrombospondins along with their receptors at varying levels in different stages of CL progression with maximum expression during the late and regressing stages in buffalo. These results are consistent with the hypothesis that Thrombospondins are negatively correlated by LH, VEGF, FGF2 and positively by $\mathrm{PGF}_{2} \alpha$, Thrombospondins also may be playing an essential modulatory role in bringing about structural and functional luteolysis stimulated by $\mathrm{PGF}_{2} \alpha$ possibly by promoting apoptosis of the luteal cells, reducing local bioavailability of proangiogenic growth factors and attenuating steroidogenesis in the luteal cells respectively. As TSP1 seems to be the most promising endogenous inhibitor of angiogenesis, therefore, it can be positioned at the crossroads between $\mathrm{PGF}_{2} \alpha$ priming of CL and its luteolysis.

\section{Acknowledgements}

We thank Director of Indian Veterinary Research Institute for providing necessary facilities for conducting this research work.

\section{Disclosure Statement}

No conflicts of interest exist.

\section{References}

1 Tsafriri A: Ovulation as a tissue remodelling process. Proteolysis and cumulus expansion. Adv Exp Med Biol 1995;377:121-140.

2 Pate JL, Johnson-Larson CJ, Ottobre J S: Life or death decisions in the corpus luteum. Reprod Domest Anim 2012;47:297-303.

3 Meidan R, Milvae RA, Weiss S, Levy N, Friedman A: Intraovarian regulation of luteolysis. J Reprod Fertil Suppl 1999;54:217-228.

4 Chouhan VS, Panda R, Yadav V, Babitha V, Khan F, Das G, Sarkar M: Expression and localizatin of vascular endothelial growth factor and its receptors in the corpus luteum during estrous cycle in water buffloes (Bubalus bubalis). Reprod Domest Anim 2013;48:810-818.

5 Mishra SR, Parmar SM, Chouhan SV, Rajesh G, Yadav PV, Bharti KM, Sarkar M: Expression and localization of fibroblast growth factor (FGF) family in corpus luteum during different stages of estrous cycle and synergistic role of FGF2 and vascular endothelial growth factor (VEGF) on steroidogenesis, angiogenesis and survivability of cultured buffalo luteal cells. Agri Gene 2015;1:53-68.

6 Mishra SR, Parmar SM, Chouhan SV, Rajesh G, Yadav PV, Bharti KM, Paul A, Sharma TG, Singh G, Sarkar M: Expression and localization of angiopoietin family in corpus luteum during diffrent stages of oestrous cycle and modulatory role of angiopoietis on steroidogenesis, angiogenesis and survivability of cultured buffalo luteal cells. Reprod Domest Anim 2016;51:1-15.

7 Fiona H, Thomas H, Wilson AS, Hamish MF: Thrombospondin-1 Expression is Increased during Follicular Atresia in the Primate Ovary. Endocrinology 2008;149:185-192.

8 Hogg PJ, Hotchkiss KA: Role of thrombospondins in vascular biology; in Berndt MC (ed): Platelets, Thrombosis and the Vessel Wall. Harwood Academic Publishers, 2000, pp 253-266.

9 Greenaway J, Gentry PA, Feige JJ, LaMarre J, Petrik JJ: Thrombospondin and vascular endothelial growth factor are cyclically expressed in an inverse pattern during bovine ovarian follicle development. Biol Reprod 2005;72:1071-1078.

10 Koumei S, Kiemi S, Motozumi M, Takashi S, Akio M: $\mathrm{PGF}_{2} \alpha$ differentially affects mRNA expression relating to angiogenesis, vasoactivation and prostaglandins in the early and mid CL in cow. J Reprod Dev 2010;56:428436. 


\section{Cellular Physiology Cell Physiol Biochem 2019;52:532-552 \begin{tabular}{l|l|l}
\hline DOI: 10.33594/000000038 & (c)19 The Author(s). Published by
\end{tabular} and BIOChemistry Published online: 22 March 2019 Cell Physiol Biochem Press GmbH\&Co. KG

11 Chouhan VS, Dangi SS, Babitha V, Verma MR., Bag S, Singh G, Sarkar M: Stimulatory effect of luteinizing hormone, insulin-like growth factor-1 and epidermal growth factor on vascular endothelial growth factor production in cultured bubaline luteal cells. Theriogenology 2015;84:1185-1196.

12 Margosio B, Rusnati M, Bonezzi K, Cordes BL, Annis DS, Urbinati C, Giavazzi R, Presta M, Ribatti D, Mosher DF, Taraboletti G: Fibroblast growth factor-2 binding to the thrombospondin-1 type III repeats, a novel antiangiogenic domain. Int J Biochem Cell Biol 2008;40:700-709.

13 Farberov S, Meidan R: Functions and Transcriptional Regulation of Thrombospondins and Their Interrelationship with Fibroblast Growth Factor-2 in Luteal Cells. Biol Reprod 2014;91:58.

14 Rajesh G, Paul A, Mishra SR, Bharati J, Thakur N, Mondal T, Soren S, Harikumar S, Narayanan K, Chouhan VS, Bag S, Das BC, Singh G, Maurya VP, Sharma GT, Sarkar M: Expression and functional role of Bone Morphogenetic Proteins (BMPs) in cyclical corpus luteum in buffalo (Bubalus bubalis). Gen Comp Endocrinol 2017;240:198-213.

15 Sarkar M, Schilffarth S, Schams D, Meyer HHD, Berisha B: The expression of leptin and its receptor during different physiological stages in the bovine ovary. Mol Reprod Dev 2010;77:174-181.

16 Liang X, Potter J, Kumar S, Zou Y, Quintanilla R, Sridharan M, Carte J, Chen W, Roark N, Ranganathan S, Ravinder N, Chesnut JD: Rapid and highly efficient mammalian cell engineering via Cas9 protein transfection. J Biotechnol 2015;208:44-53.

17 Pfaffl MW: A new mathematical model for relative quantification in real time RT-PCR. Nucleic Acids Res 2001;29:e45.

18 Garrido C, Saule S, Gospodarowicz D: Transcriptional regulation of vascular endothelial growth factor gene expression in ovarian bovine granulosa cells. Growth Factors 1993;8:109-117.

19 George WS, Rina M: Ever-changing cell interactions during the life span of the corpus luteum: Relevance to luteal regression. Reprod Biol 2014;14:75-82.

20 Berisha B, Schams D, Rodler D, Sinowatz F, Pfaffl WM: Expression and localization of members of the thrombospondin family during final follicle maturation and corpus luteum formation and function in the bovine ovary. J Reprod Dev 2016;62:501-510.

21 Higuchi T, Fujiwara H, Yamada S, Tatsumi K, Kataoka N, Itoh K, Maeda M, Fujita J, Fujii S: Co-expression of integrin-associated protein (IAP/CD47) and its ligand thrombospondin-1 on human granulose and large luteal cells. Mol Hum Reprod 1999;5:920-926.

22 Isenberg JS, Martin-Manso G, Maxhimer JB, Roberts DD: Regulation of nitric oxide signalling by Thrombospondin1: implications for anti-angiogenic therapies. Nat Rev Cancer 2009;9:182-194.

23 Kanda S, Shono T, Tomasini-Johansson B, Klint P, Saito Y: Role of thrombospondin- derived peptide, 4N1K, in FGF-2-induced angiogenesis. Exp Cell Res 1999;252:262-272.

24 Zalman Y, Klipper E, Farberov S, Mondal M, Wee G, Folger JK: Regulation of angiogenesis-related prostaglandin F2alpha-induced genes in the bovine corpus luteum. Biol Reprod 2012;86:92.

25 Mirochnik Y, Kwiatek A, Volpert OV: Thrombospondin and apoptosis: molecular mechanisms and use for design of complementation treatments. Curr Drug Targets 2008;9:851-862.

26 Garside SA, Harlow CR, Hillier SG, Fraser HM, Thomas FH: Thrombospondin-1 inhibits angiogenesis and promotes follicular atresia in a novel in vitro angiogenesis assay. Endocrinology 2010;151:1280-1289.

27 Colombo G, Margosio B, Ragona L, Neves M, Bonifacio S, Annis DS: Non-peptidic thrombospondin-1 mimics as fibroblast growth factor-2 inhibitors: an integrated strategy for the development of new antiangiogenic compounds. J Biol Chem 2010;285:8733-8742.

28 Greenaway J, Lawler J, Moorehead R, Bornstein P, Lamarre J, Petrik J: Thrombospondin-1 Inhibits VEGF Levels in the Ovary Directly by Binding and Internalization Via the Low Density Lipoprotein ReceptorRelated Protein-1 (LRP-1). J Cell Physiol 2007;210:807-818.

29 Wang S, Wu Z, Sorenson CM, Lawler J, Sheibani N: Thrombospondin-1-deficient mice exhibit increased vascular density during retinal vascular development and are less sensitive to hyperoxia mediated vessel obliteration. Dev Dyn 2003;228:630-642.

30 Meidan R, Girsh E, Blum O, Aberdam E: In vitro differentiation of bovine theca and granulosa cells into small and large luteal-like cells: morphological and functional characteristics. Biol Reprod 1990;43:913921.

31 Maroni D, Davis JS: TGFB1 disrupts the angiogenic potential of microvascular endothelial cells of the corpus luteum. J Cell Sci 2011;124:2501-2510. 
Cellular Physiology Cell Physiol Biochem 2019;52:532-552

\begin{tabular}{ll|l|l|l} 
DOl: $10.33594 / 000000038$ & O 2019 The Author(s). Published by \\
and Biochemistry Published onlin:22
\end{tabular}

Paul et al.: Thrombospondins and Corpus Luteum Function

32 Berisha B, Schams D, Kosmann M, Amselgruber W, Einspanier R: Expression and tissue concentration of vascular endothelial growth factor, its receptors, and localization in the bovine corpus luteum during estrous cycle and pregnancy. Biol Reprod 2000;63:1106-1114.

33 Kwak C, Jin RJ, Lee C, Park MS, Lee SE: Thrombospondin-1, vascular endothelial growth factors expression, and their relationship with p53 status in prostate cancer and benign prostate hyperplasia. BJU Int 2002;89:303-309.

34 Yamashita H, Kamada D, Shirasuna K, Matsui M, Shimizu T, Kida, K, Berisha B, Schams D, Miyamoto A: Effect of local neutralization of basic fibroblast growth factor or vascular endothelial growth factor by a specific antibody on the development of the corpus luteum in the cow. Mol Reprod Dev 2008;75:1449-1456.

35 Robinson RS, Nicklin LT, Hammond AJ, Schams D, Hunter MG, Mann GE: Fibroblast growth factor 2 is more dynamic than vascular endothelial growth factor A during the follicle-luteal transition in the cow. Biol Reprod 2007;77:28-36. 